\title{
La mujer en los mosaicos bizantinos raveneses (siglos V - VII)
}

Recibido: 25/08/2019. Aceptado: 25/10/2019.

\section{Resumen $^{1}$}

La técnica musivaria como mecanismo decorativo y narrativo era usada desde la Antigüedad y el Cristianismo abrevó ampliamente en ella con la finalidad de desarrollar ciclos iconográficos propios de propaganda, trasladándola a muros y techos, narrando de mil maneras diversas el mensaje cristiano en templos y palacios, apoderándose de recursos estéticos y narrativos romanos, de manera tal que el mosaico superó largamente a la pintura entre los siglos IV y VIII. El principal objetivo de este artículo es analizar a las mujeres retratadas o comitentes en mosaicos raveneses entre los siglos V y VII, fuesen santas, nobles, plebeyas, pecadoras o virtuosas.

PALABRAS CLAVE: Ravena, mosaico, mujer, Bizancio, Cristianismo

\section{The woman in the Ravenan Byzantine mosaics (5th to 7th centuries)}

\begin{abstract}
The musivarian technique, as a decorative and narrative mechanism, was used since Antiquity and Christianity drew extensively on it in order to develop its own propaganda iconographic cycles, transferring it to walls and ceilings, narrating in a thousand different ways the christian essage in temples and palaces, seizing Roman aesthetic resources and narratives, in such a way
\end{abstract}

1 Este artículo es parte del Proyecto Pict PICT-2017-0387 "La narrativa en Bizancio temprano (ss. iv-ix)", dirigido por el Dr. Pablo A. Cavallero, FFyL - UBA. 
that the mosaic greatly surpassed painting between the 4 th and 8 th centuries. The main object of this article is to analyze the women portrayed or clients in ravenan mosaics between the 5th and 7th centuries, whether they were holy, noble, plebeian, sinful or virtuous.

KEYWORDS: Ravenna, mosaic, woman, Byzantium, Christianity

"Aula claris radiat speciosa metallis / in qua fidei lux pretiosa micat" 2

\section{Nota preliminar}

El mosaico es una de las más nobles y complejas técnicas de decoración de todo tipo de superficies que desde la Antigüedad, ha engalanado vastas superficies a lo largo y ancho del Mediterráneo y el Oriente Próximo. Su retórica en piedra, plena de color y textura, ha servido a lo largo de siglos para la exposición de programas iconográficos profanos o religiosos, pero siempre en un marco de lujo, esplendor y uncialidad, ofreciendo en su soporte, un marco ideal para la exaltación de mensajes y personajes políticos, verdades de la Fe o relatos anagógicos y místicos. El legado romano de esta técnica a la Edad Media es innegable y, recuperado en Bizancio, retornó a Europa con el intento de reconstrucción imperial que Justiniano intentará realizar en el siglo VI. Ravena fue la capital del Imperio Romano de Occidente (402-476), gracias a una decisión de Honorio, quien puso a esta ciudad del norte ubicada entre el Véneto y las Marcas en una posición de absoluto privilegio frente a otras ciudades y por supuesto, frente a la decadente y decaída Roma. ${ }^{3}$ Esta decisión fue tomada fundamentalmente debido a su posición geográfica protegida por ciénagas y pantanos de difícil acceso. Posteriormente llegó a ser la brillante capital de Teodorico tras vencer a Odoacro (493-526). ${ }^{4}$

En el 540 Ravena fue recuperada duramente por el general Belisario a nombre del emperador Justiniano y, aunque nuevamente caída en poder ostrogodo, quedará finalmente en manos bizantinas, al ocuparla el general Narsés en 552. La fundación del Exarcado de Ravena hacia el 568 la transformó en una suerte de virreinato bizantino con poderes tanto militares como civiles y de cara al peligro ostrogodo y posteriormente lombardo (cfr. Figura 1). De todas maneras, la lejanía con la Metrópoli y los avatares con lombardos y luego con francos, sumió a Ravena en una dificultosa posición entre Roma y la Metropoli de Constantinopla, a la vez que fue asediada por el arrianismo y la Crisis Iconoclasta más tarde. Tras el asesinato del último exarca Eutiquio en 751, la capital del nuevo catapanato de Italia fue trasladada a Bari, la que caería a su vez en el 858 en poder musulmán. Las tierras del antiguo exarcado fueron reclamadas por el Papa Esteban II a su nuevo aliado, Pipino el Breve, quien se las donara en el 756, lo cual fue confirmado posteriormente por su hijo, Carlomagno, dando así nacimiento al Patrimonio de San Pedro y provocando la desaparición definitiva del poder ravenés en el norte de Italia.

2 "El magnífico atrio resplandece de oro /aquí brilla la más preciosa luz de la fe". Texto en el ábside de San Cosme y San Damián de Roma.

3 Para más datos, cfr. Kean (2013) o Wickham (1981).

4 Luego de haber estado diez años prisionero en Constantinopla, cuando estuvo en Ravena, imitó el estilo imperial con profundas influencias milanesas y romanas sumadas a la inspiración que Constantino ejercía sobre él. Arriano, pero tolerante en materia religiosa, es un buen ejemplo de bárbaro ilustrado. 


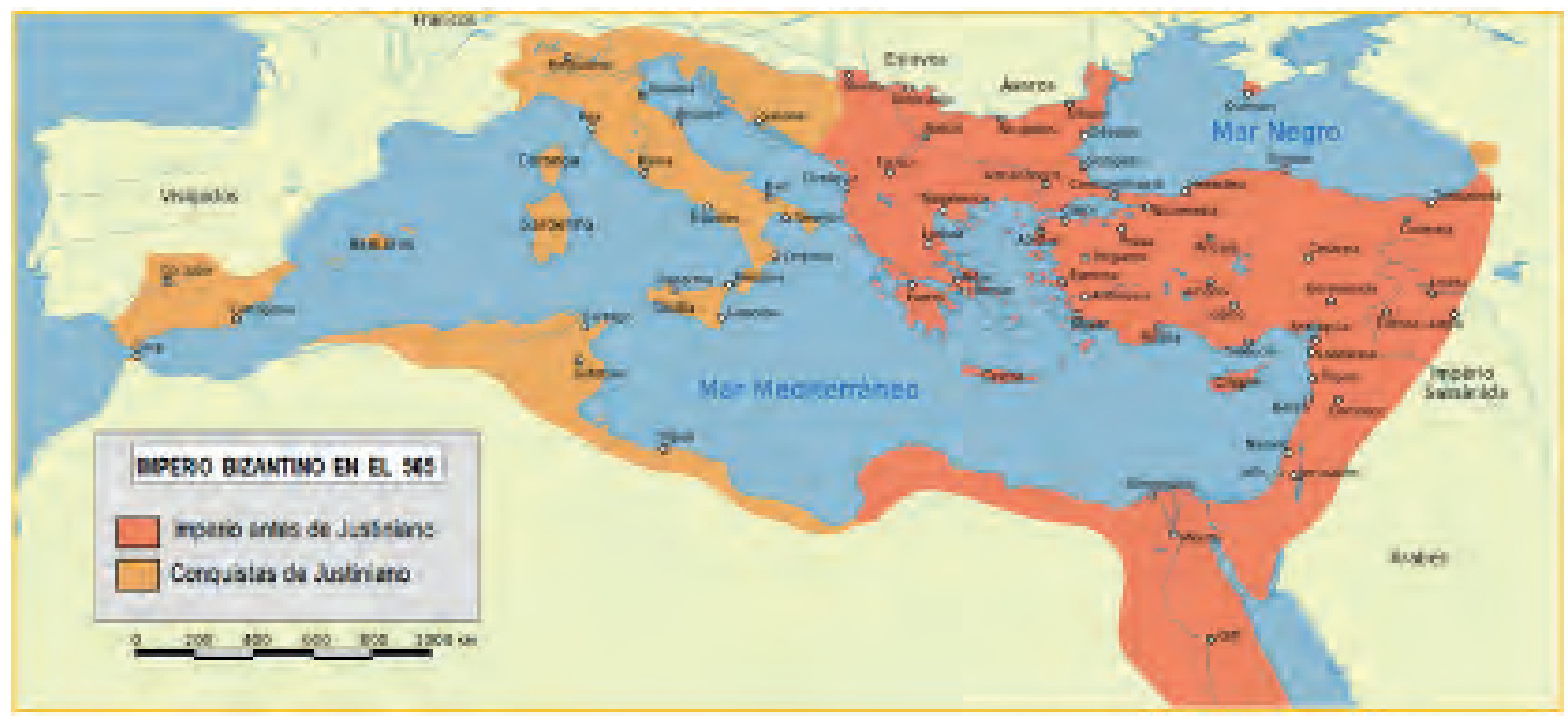

Figura 1. Mapa del Imperio Bizantino en la época justinianea.

En este artículo no pretendemos más que brindar una mirada sobre la retórica y 'relato pétreo' que algunos mosaicos raveneses de los siglos VI y VII han dedicado a la mujer, ya sea como comitente o protagonista, lo que nos muestra que desde muy temprano la presencia de lo femenino en el arte musivario medieval es de real importancia.

\section{Ravena. Mujeres. Mosaicos}

Por ser Ravena una ciudad medianamente alejada de los principales centros del poder y bajo poder pontificio hasta 1796, sus tesoros artísticos sobrevivieron prácticamente sin modificaciones desde la Temprana Edad Media, por lo que a la fecha, un puñado de construcciones conforman un legado invalorable de arte, política y religión. A pesar de haber sido repetidamente saqueada, expoliada e incluso bombardeada en 1944, la mayoría de los edificios y mosaicos raveneses han perdurado, lo que nos permite realizar una aproximación a su análisis y ver emerger a las mujeres que en ellos se encuentran, como protagonistas indiscutibles dentro de una producción que de seguro fue mayor, pero que, con lo que nos ha llegado, nos permite realizar un estudio respecto del papel jugado por ellas en ellos. ${ }^{5}$

El origen de la técnica musivaria ${ }^{6}$ podemos encontrarlo en Mesopotamia, miles de años antes de Roma y de la era cristiana. Pequeñas piezas de cerámica

5 Sobre los primeros siglos del arte cristiano y el período justinianeo, cfr. Grabar (1960; 1971), Talbot Rice (2000), Bertelli (2012), Ferraiuolo (2018) Passerino; Bovini (2006), Beckwith (1997).

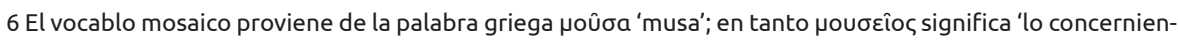
te a las musas' y finalmente nou cîov, 'el templo de las musas', o más sencillamente 'lugar donde residen

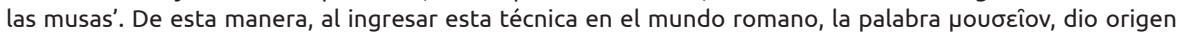
al término latino musivus, que podemos considerar como el antecedente de mosaico. De la misma manera que los romanos consideraban a los museos, como hogar de las musas, esta técnica decorativa de tan alta calificación técnica y belleza formal, era considerada como de factura o inspiración surgida de las musas o artistas señalados por ellas. Para más datos sobre el origen de esta técnica, cfr. Rossi (1970). Algunas de las técnicas más conocidas en la Antigüedad y Edad Media para la elaboración de éstos eran: opus vermiculatum: su origen era egipcio y se hacía con unas piedras / teselas muy pequeñas, incluso hasta más de 60 por metro cuadrado, con las cuales el artista podía dibujar con bastante facilidad las curvas, las siluetas y toda 
coloreada y horneada formaban verdaderos tapices para el suelo de las estancias palaciegas o decoración de muros y columnas. Esta técnica fue adoptada más tarde por los griegos, quienes usaron pequeños guijarros de colores para la formación de diseños; aunque la ciudad de Alejandría, durante el Helenismo, fue la auténtica capital de esta técnica, la que pasaría al mundo romano y de allí a su 'internacionalización' por todo el Mediterráneo.

Con Roma, la suntuosidad de los mosaicos parietales o de auténticas alfombras de piedra llegó a su máximo esplendor, a juzgar por la temática y complejidad técnica de los restos que llegaron a nosotros. Se usaron teselas de mármol, vidrio, nácar, cerámicas vitrificadas, etc., en diseños que evocaban relatos de escenas de la vida cotidiana, proezas de héroes, mitología o tan sólo dibujos geométricos, configurando una especialización altamente costosa, dado que existía un equipo de trabajo usualmente conformado por un pictor imaginarius (el que realizaba el dibujo o sinopia que luego se trasluciría en un mosaico), un lapidarius structor (maestro artesano de la piedra), un magister musearius (el que colocaba las teselas, también conocido como tesellarii) y un calcis coctor (que era quien preparaba el mortero con el que se fijaría el diseño a la superficie elegida, también llamado pavimentarius); además de un magister vitrarius (quien fundía el vidrio y preparaba las placas con material teselar vitrificado) y un pictor parietarius, si los mosaicos iban a ser fijados en superficies murarias. ${ }^{7}$

Con el traslado de la capital a Bizancio, Constantino le dio nuevo impulso a una industria suntuaria que agregaría el oro en sus diseños, apareciendo el primer lenguaje cristiano aplicado a esta técnica con una finalidad fundamentalmente pedagógica como auténtica Biblia pauperum, que ha desarrollado amplios ciclos relatando las principales verdades del cristianismo, sus personajes esenciales o la propaganda política de los comitentes de tales obras. Más tarde, el Islam también adoptará la técnica musivaria con gran maestría imitando modelos y técnicas bizantinas, pero luego desarrollará una iconografía completamente diversa de la cristiana y acabará por abandonar esta técnica, prefiriendo la del azulejo, con inigualables resultados artísticos. ${ }^{8}$

clase de objetos que pudieran requerir precisión. Luego se colocaban las teselas en hilera continua que seguía las líneas del contorno y del dintorno, es decir, respecto del límite de las principales partes internas de las figuras que se quería dibujar. Esa denominación proviene del diminutivo latino vermiculus (de vermis, gusano), dado que asemejaba a la sinuosidad de su cuerpo. Es de gran belleza pero muy fatigoso el trabajo de armado de cada pieza. Opus musivum era el tipo de mosaico propio para superficies murarias y empezó a ser utilizado a finales del s. Ill y será el que mayormente desarrolle el mundo bizantino. El opus sectile implicaba la elaboración de verdaderos ciclos iconográficos pero con recortes de piedras u otros materiales con teselas más grandes y consistía en recortar placas de mármol de diversos colores para componer las figuras, ya fuesen geométricas, animales o personas. Uno de los mejores ejemplos de esta técnica se conservan en el Palatino de Roma, en el Palacio de Flavio. El opus signinum, originario de Signia en el Lacio, era una técnica que utilizaba teselas fundamentalmente en negro y blanco para los diseños y que se aplicaban una por una sobre el pavimento fresco o trozos de cerámica más toscos. Además, en esta región había numerosas fábricas de tejas y de ellas se obtenía un polvo que, al mezclarse con cal, generaba un cemento muy duro e impermeable, hoy conocido como 'tierra romana'. Este producto se empleó bastante en toda Italia y en Occidente para crear los suelos y como revestimiento de piscinas, cubas de salazón, pozos de agua, etc. A veces, para darle más consistencia se añadía a la masa guijarros y piedras machacadas. El opus lapilli era el diseño que se realizaba con piedrecillas de colores pero separadas las partes de las figuras con listones de plomo o bronce. Muchas veces se usaba material expulsado por volcanes para este trabajo. El Opus tessellatum se hacía con teselas cúbicas iguales y de distintos tonos. Era apto para formas geométricas pero no para figurativas. Solía combinarse en Roma con el Opus vermiculatum. Finalmente, el Opus emblemata, era un tipo de mosaico que se preparaba en el taller y luego de colocaba al modo de las actuales baldosas, ya que se lo elaboraba y fraguaba en una suerte de cajas o sobre lajas de mármol. Cfr. Roncuzzi; Fiorentini (2001), Kiecol (2017), Concina; Flores David; Guidetti (2011); Rizzardi (2011), Rizzardi (2005).

7 Castelnuovo; Sergi (2013).

8 Kiecol (2017:16ss.) 
Durante la temprana Edad Media el mosaico es una delicada técnica que expresa una retórica en piedra y que a lo largo de un verdadero tapiz pétreo puede desarrollar ciclos iconográficos completos o ser meramente un marco decorativo para cualquier superficie a cubrir. Es la resultante de la imprimación de una superficie con una serie de capas de material adherente respecto del muro y de las piezas colocadas con diversas técnicas, llamadas teselas, las que están fabricadas con trozos de piedras de colores o semipreciosas, a la vez que obleas de material cerámico con algún pigmento coloreado u hojas de oro, las que son cubiertas con pasta de vidrio y horneadas para quedar vitrificadas y con color permanente e inalterable. Se emplean cubos de vidrio más ligeros y que reflejan mejor la luz alternándose con piezas opacas, cubriendo las paredes previamente preparadas y con mortero fresco. El resultado final del diseño traduce la posibilidad de ver el intersticio entre tesela y tesela, pero visto a la distancia, un mosaico semeja a una pintura impresionista, donde los colores se funden generando las imágenes descriptas y perdiéndose la 'imperfección' técnica de la unión entre piezas. Cuanto más prieta es la textura y menos se puedan ver los espacios entre teselas, mayor es la maestría del pictor imaginarius y del magister musearius. ${ }^{9}$ La ligereza y esplendor cromático es otro elemento característico de la musivaria de este momento, pues no sólo transmite el fulgor y brillo inherentes al lujo y al poder, sino que también simbolizan la luz y la divinidad que pretende caracterizar a los interiores de los templos. Los artífices bizantinos se convirtieron de esta manera en auténticos maestros del arte del mosaico durante siglos, responsables también de transmitirlo por otras zonas geográficas y culturas artísticas.

Con posterioridad Teófilo escribirá hacia el s. XII su Schedula diversarum artium, en la que explica varias de las más prestigiosas técnicas antiguas y medievales para la confección de objetos de uso litúrgico, decoración musivaria como así también, la función del artesano y la pedagogía que el arte produce en el fiel. ${ }^{10}$ En este sentido, la perdurabilidad y prácticamente inalterabilidad del mosaico, lo hizo pieza clave en la decoración durante los primeros siglos medievales, cuando su lujo y alto costo de elaboración indicaban la procedencia regia y valor agregado por su confección. Estas mismas características que fueron positivas en determinado período para la decoración de templos y palacios, lo hizo demasiado oneroso y poco atractivo hacia la época carolingia, cuando los artesanos musivarios debían venir necesariamente desde el norte de Italia, pues era donde se conservaba la técnica; el dispendio que representaba, sumado a los cambios en el gusto posteriores, nos han dejado muy pocos testimonios para su análisis y valoración.

El marcado policentrismo político y de producción artística tardoantiguos posibilitaron la difusión de la técnica del mosaico, magnificando la cantidad de testimonios que perduraron. En Milán, capital imperial con cierta estabilidad entre el 286 y 402, se conservan numerosos restos, como en el mausoleo de San Aquilino (del cual se conservan importantes fragmentos) o en San Lorenzo (aunque severamente dañados en el incendio de 1070). Roma y Bizancio fueron centros de producción musivaria portentosos y Ravena, ya en vísperas de recibir a las autoridades imperiales y a los nuevos reinos surgidos a la caída de Roma, generó una importante cantidad de ejemplos donde conviven diversas

9 Estas tareas ya estaban perfectamente reguladas en el mundo romano, tal como atestigua el Edictum de Pretiis del 301, emanado por el emperador Diocleciano. Cfr. Reginelli (2017), Kean (2013). Sobre la técnica: Belting (2009:cap.III).

10 Gearhart (2010). 
técnicas y artesanos de distinta procedencia para elaborar encargos regios y hasta imperiales. En esta ciudad podemos contemplar diversas expresiones de mosaicos con mujeres protagonizándolos, pudiendo realizar la siguiente clasificación o distribución en su temática:

\begin{tabular}{cc}
\hline \multicolumn{2}{c}{ MUJERES } \\
\hline En relación a lo terrenal & En relación a lo divino \\
\hline $\begin{array}{c}\text { REGIAS / PALATINAS / NOBLES / } \\
\text { MUNDANAS }\end{array}$ & MARÍA / SANTAS / MÁRTIRES \\
\hline
\end{tabular}

De esta forma y según esta división en dos grandes grupos de mujeres retratadas, diversos ámbitos espaciales contienen referencias a estas damas de las que por alguna u otra causa, es menester la presencia: por ser parte de algún relato bíblico o evangélico, por alguna causa política o encargo de una comitente, por evocación a la Virgen o a santas en particular, o por la necesidad de presentar en el plan divino a mujeres y varones en igualdad de condiciones y de cara a la Salvación de la Humanidad.

El mecenazgo de Gala Placidia (¿388?-450) fue notorio y decisivo en esta visión politizada del uso del mosaico y la presencia de las mujeres en él. Hija de Teodosio I y de Gala, su segunda esposa, fue emperatriz consorte de Constancio III, madre de Valentiniano III y medio hermana de Honorio y Arcadio. ${ }^{11}$ Importante comitente artística, de sus encargos sólo subsiste parte de la Iglesia de la Santa Cruz (hoy en proceso de restauración para convertirla en centro cultural o sala de exposiciones, pero completamente desafectada de su función religiosa) ${ }^{12}$ y el célebre Mausoleo de Gala Placidia, el cual no conserva su tumba pero sí un exquisito programa iconográfico que cubre en su integridad las paredes y el techo abovedado. Este 'mausoleo' se encontraba al final del nártex de aquél edificio que sobrevive bastante expoliado a la fecha. Tiene planta en cruz latina, único exponente regional de semejante tipología, ${ }^{13}$ y a lo largo de los siglos fue expoliado y dañado por intervenciones poco afortunadas. Recién desde mediados del s. XX empezaron a hacerse trabajos serios para su rescate y puesta en valor, además de profundos estudios arqueológicos ${ }^{14}$ (cfr. Figuras 2 y 3 ). Resalta su importancia el uso de planta en cruz latina con tres naves, cuyos mejores ejemplos hay que buscarlos para la época en Milán (la Basilica Apostolorum y la Basilica Virginum, hoy San Simpliciano, construidas bajo el obispado de San Ambrosio) y con el modelo de la Basílica de los Apóstoles de Constantinopla, mandada a construir por Constantino gracias al incentivo de su madre, Santa Helena. Si bien estas iglesias fueron construidas en honor de los Apóstoles y mostrando el triunfo de la Cruz, la originalidad de Ravena es que directamente está enlazando a dos poderosas mujeres comitentes: Gala Placidia y Santa Helena con la Santa Cruz, la que, según la tradición, fue descubierta por la madre del emperador y traída a Italia.

11 Una interesante, aunque breve biografía en perspectiva de género está contenida en: AA. VV. (2010). Se trata de una obra colectiva de escritoras e investigadoras que presentan una biografía femenina a través de la historia para cada día de un año. La primera en ser reseñada, es Gala Placidia.

12 David (2013), Coscarella; De Santis (2012), Cortesi (1978).

13 Deliyannis (2010:74-84).

14 Cereda; Dall'Ara (2014), Cirelli (2008). Otro meduloso estudio con ilustraciones históricas, fotografías antiguas y relevamiento historiográfico completo es Novara; Rinaldi (2013). 


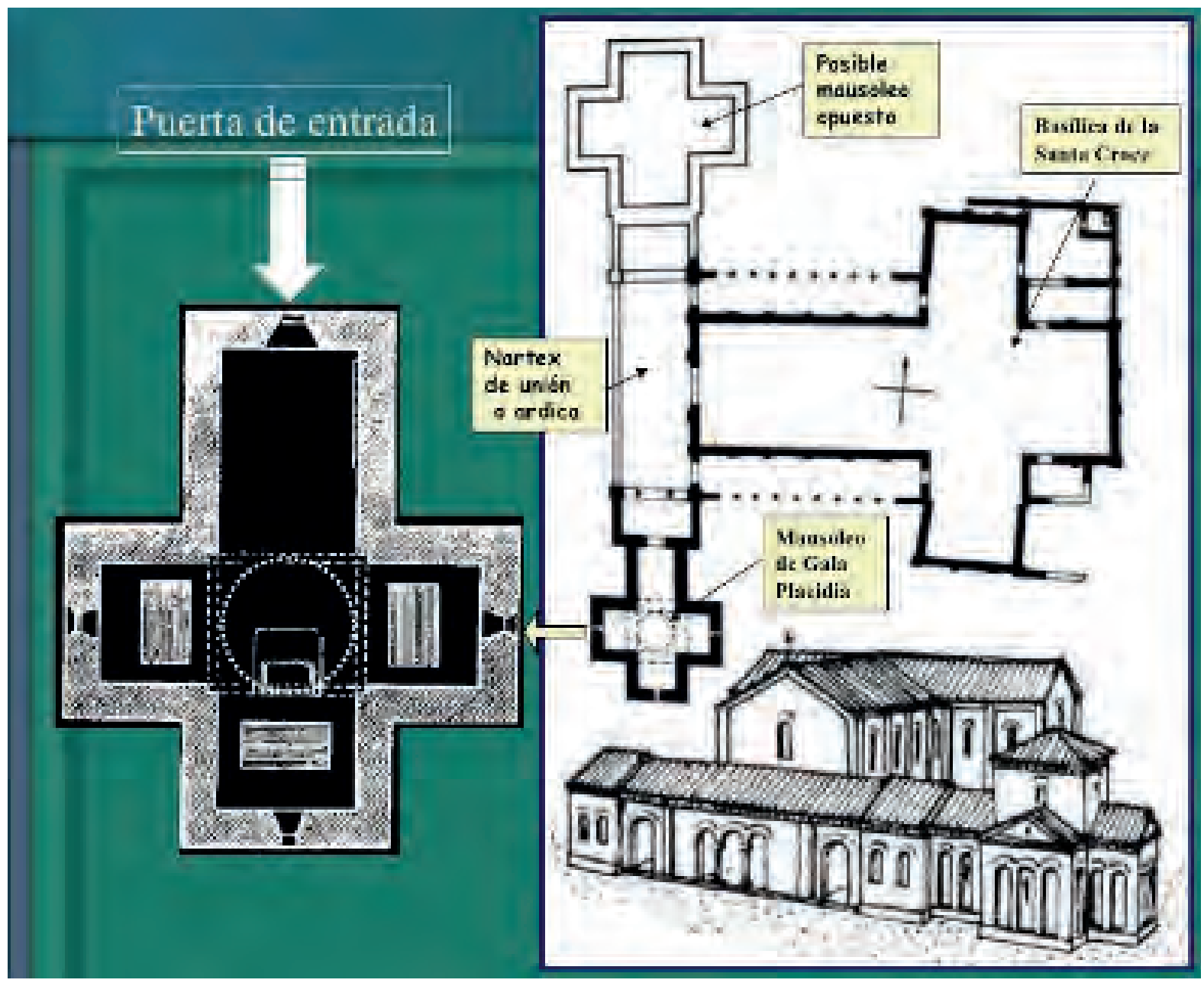

Figura 2. Izquierda: Planta actual del Mausoleo de Gala Placidia. Derecha: planta del conjunto monumental de la Santa Croce. Debajo: Posible alzado de todo el conjunto.

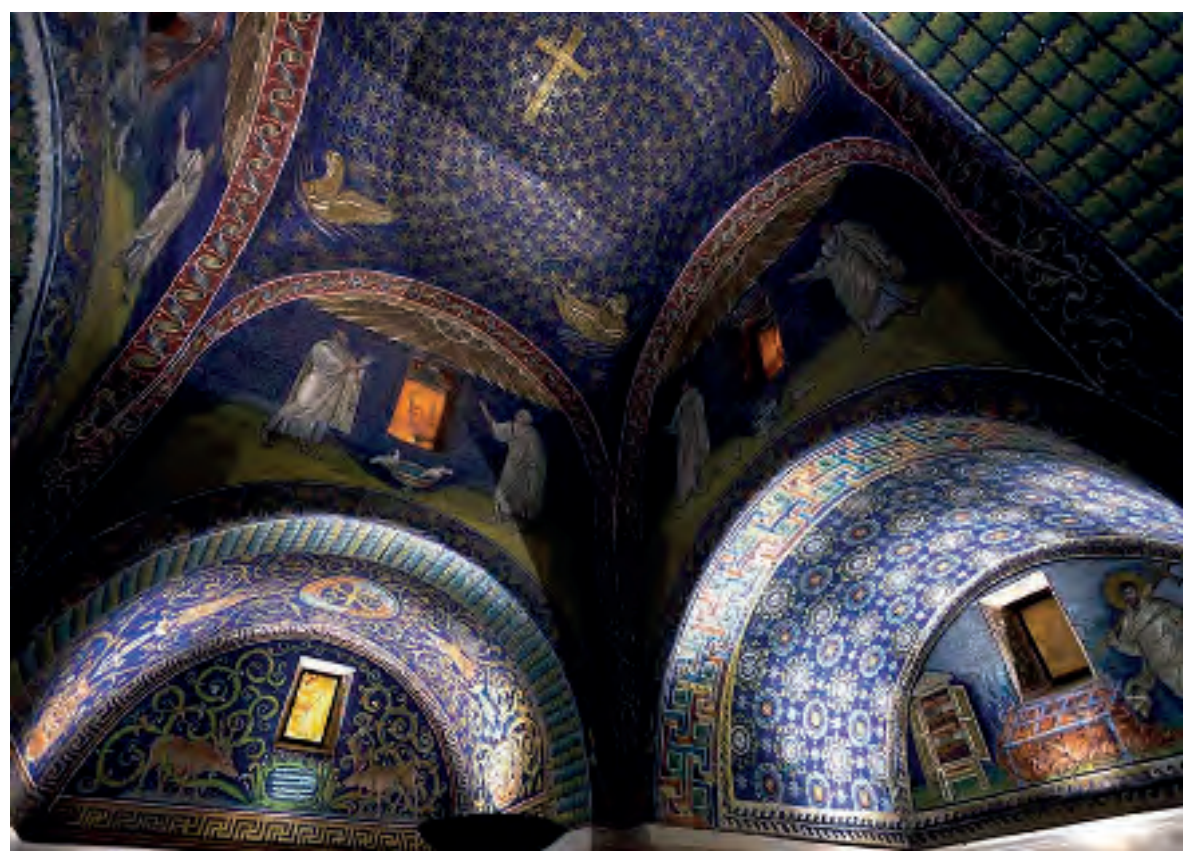

Figura 3. interior del Mausoleo de Gala Placidia. 
Otro importante encargo de Gala Placidia fue su Capilla Palatina, hoy San Juan Evangelista, exvoto por haberse salvado de un naufragio durante una tempestad marina a su llegada a Ravena en el 424 desde Constantinopla ( $c f r$. Figura 4). También muy restaurada, fue víctima de bombardeos en 1944 (cfr. Figuras 5 y 6), por lo que mucho de su programa iconográfico es conocido a través de restos arqueológicos, fotos antiguas o descripciones en sermones del obispo Agnello. Este explícito programa político contenido en su arco de triunfo y en la calota absidal mostraba la familia de la Augusta en plena travesía, salvada por el Evangelista y el Redentor mismo. De esta manera, se reutilizan topoi: la Nave/Iglesia es timoneada por Cristo y se encamina hacia su triunfo, que se transforma en la nave salvada por la Divinidad, donde la emperatriz y sus hijos legítimos se encontraban y que al salvarse, se asegura su triunfo político. ${ }^{15}$ Desgraciadamente sólo sobreviven trozos muy deteriorados de este mosaico y fotografías previas a la guerra, pero las referencias textuales, permiten entrever la magnificencia de esta obra donde la emperatriz presidía el mismísimo Arco Triunfal de una iglesia en compañía de sus vástagos y del Salvador. (cfr. Figura 7).

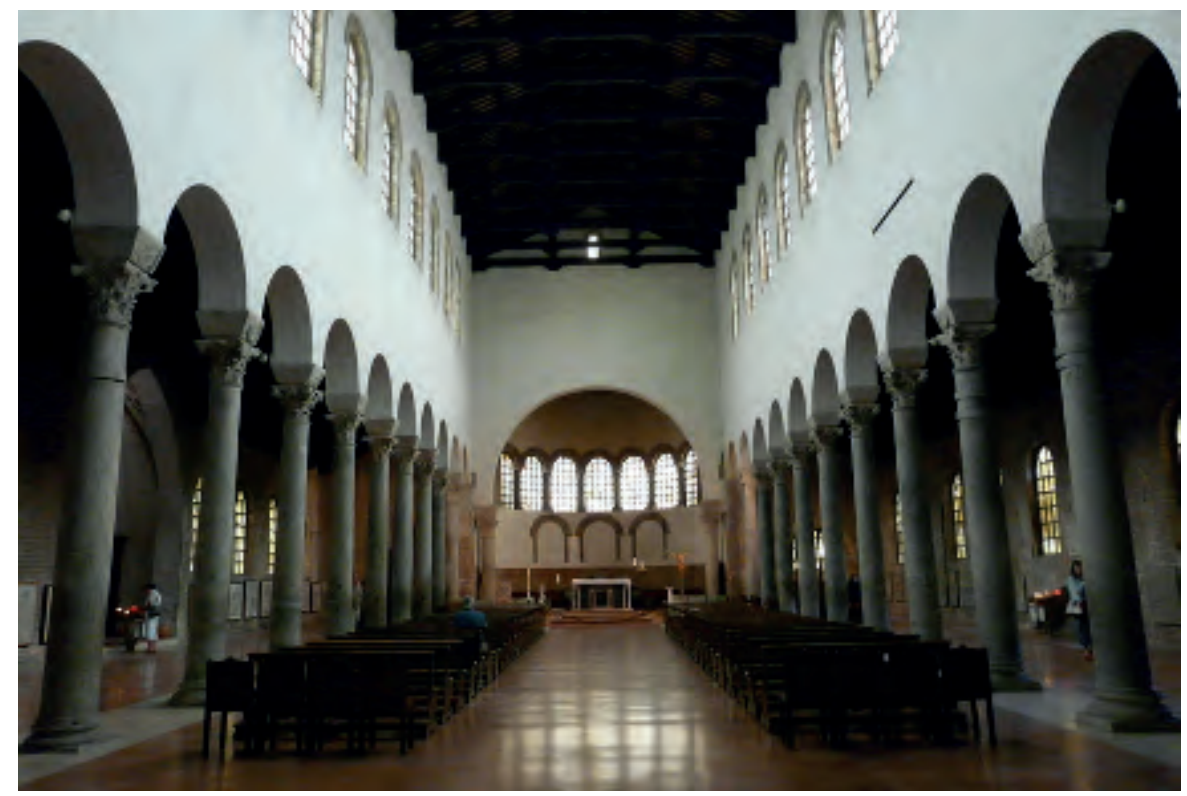

Figura 4. Vista interior de San Giovanni Evangelista en la actualidad.

15 En la cima del arco triunfal, aparecía Gala Placidia con sus hijos en una nave, salvados por el Evangelista. Ambas escenas se encontraban sobre la inscripción "Galla Placidia Augusta pro se et his omnibus hoc votum solvent" y la inscripción completa en la calota absidal era: "Sanctus loa[nn]es Evangelista. // Amore Christi nobilis / et filius tonitrui / Sanctus lohannes arcana vidit / Galla Placidia Augusta / pro se et his omnibus / hoc votum solvit // D(ivus) Constantinus / d(ivus) Theodosius / d(ivus) Arcadius / d(ivus) Honorius / Theodosius n(obilissimus) p(uer) // d(ivus) Valentinianus / d(ivus) Gratianus / d(ivus) Constantinus / Gratianus n(obilissimus) p(uer) / loannes n(obilissimus) p(uer) // D(ominus) n(oster) Theodosius / d(omina) n(ostra) Eudocia // d(ominus) n(oster) Arcadius / d(omina) n(ostra) Eudoxia Aug(usta). // Sancto ac beatissimo / apostolo Iohanni Evangelistae / Galla Placidia Augusta / cum filio suo / Placido Valentiniano Augusto / et filia sua / lusta Grata Honoria Augusta / liberationis pericul(or)um maris / votum solvent. // Beati misericordes quoniam miserebitur Deus. // Confirma hoc Deus / quod operatus es in nobis / a templo tuo lerusalem / tibi offerent reges munera." [San Juan Evangelista. Por el amor de Cristo, el noble e "hijo del trueno" San Juan vio los arcanos. Gala Placidia Augusta, por sí misma y por todos estos cumple este voto. El divino Constantino, el divino Teodosio, el divino Arcadio, el divino Honorio, el nobilísimo Teodosio hijo, el divino Valentiniano, el divino Graciano, el divino Constantino Graciano nobilísimo hijo, Juan nobilísimo hijo, nuestro señor Teodosio, nuestra señora Eudocia, nuestro señor Arcadio, nuestra señora Eudoxia Augusta, Gala Placidia Augusta con su hijo Plácido Valentiniano Augusto y con su hija Grata Honoria Augusta, cumplen este voto, por la liberación de los peligros del mar, al santo y beatísimo Apóstol Juan Evangelista. "Felices los misericordiosos, porque Dios tendrá misericordia". Confirma, Dios, lo que has obrado en nosotros desde tu templo Jerusalén. Los reyes te ofrecerán dones]. (Agnellus of Ravenna. MGH VI-IX:265-391). Cfr. Deliyannis (2004), Farioli Campanati (1991), Novara Piolanti (1996). 


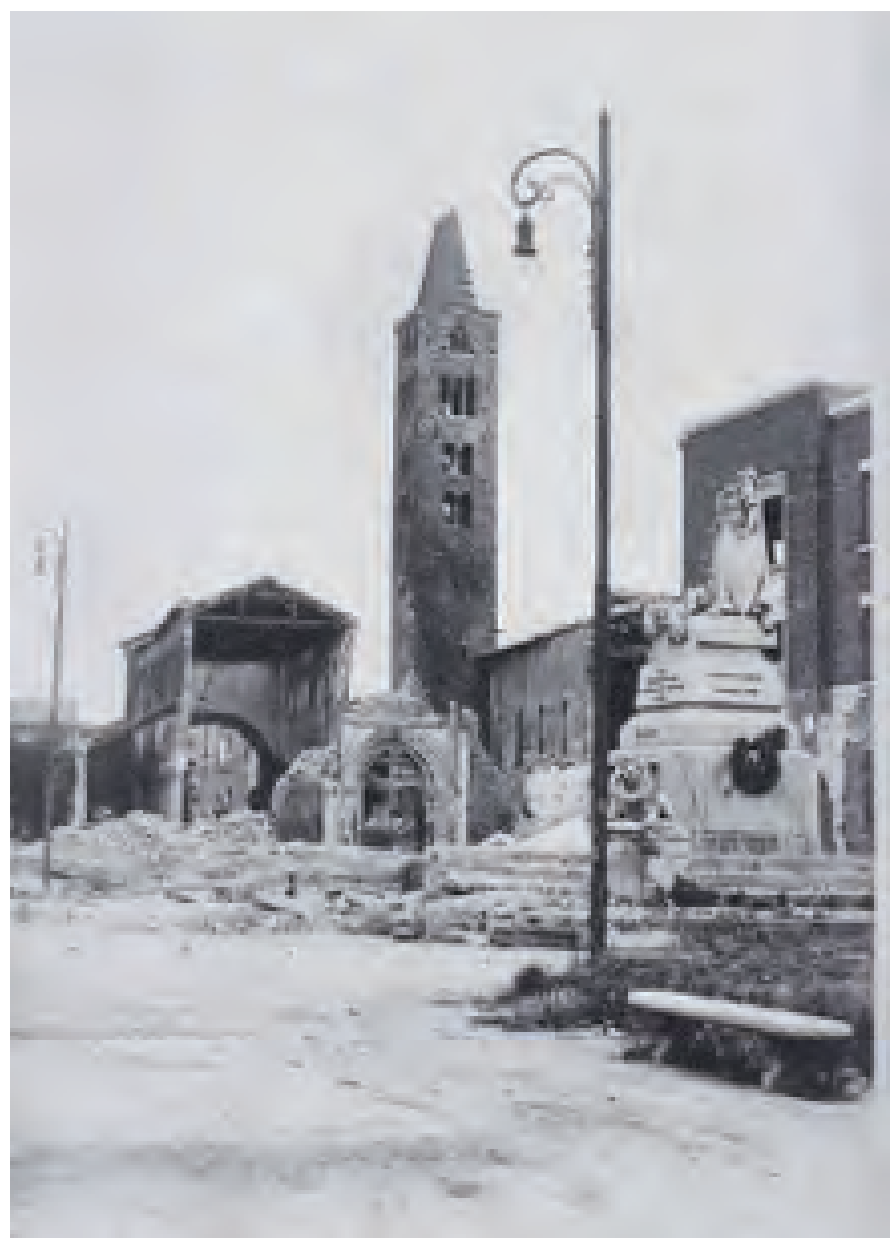

Figura 5. Vista de San Giovanni Evangelista bombardeada en 1944.

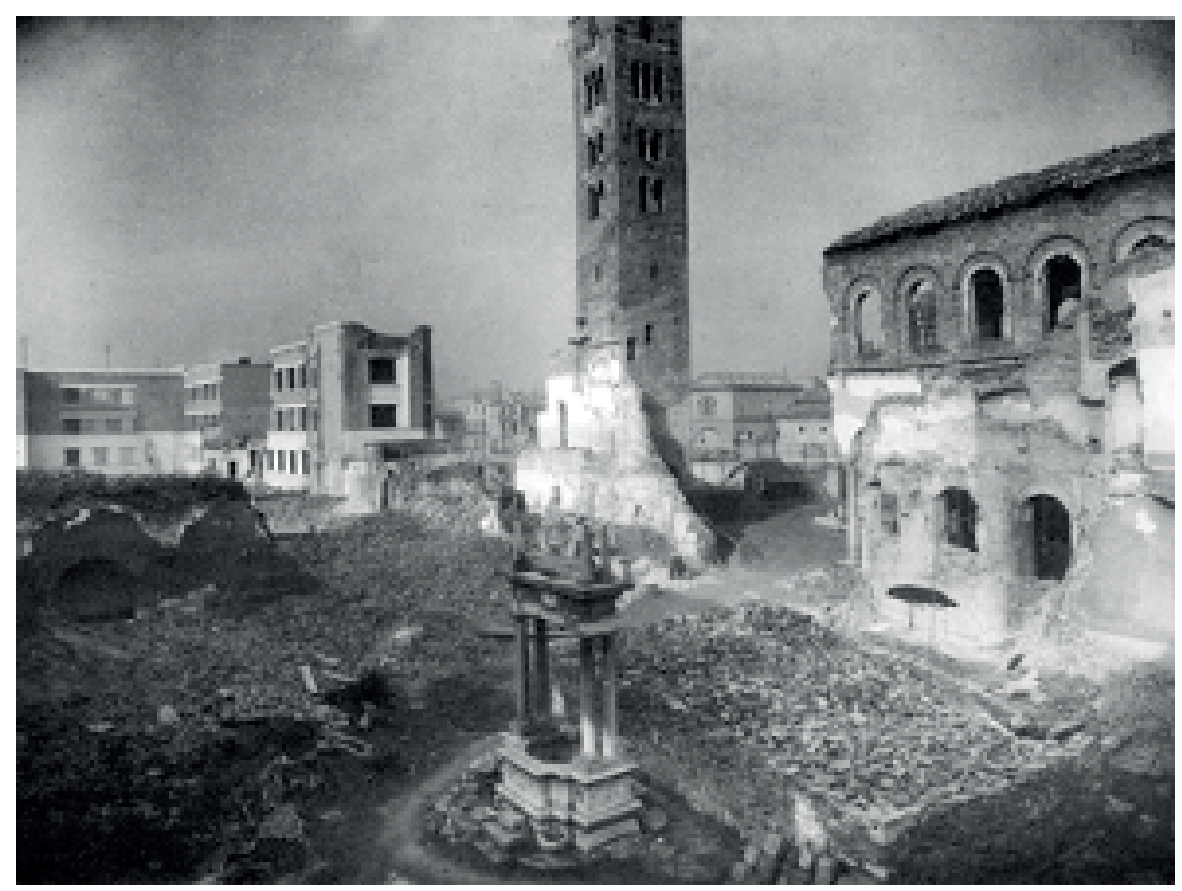

Figura 6. Vista de San Giovanni Evangelista bombardeada en 1944. 


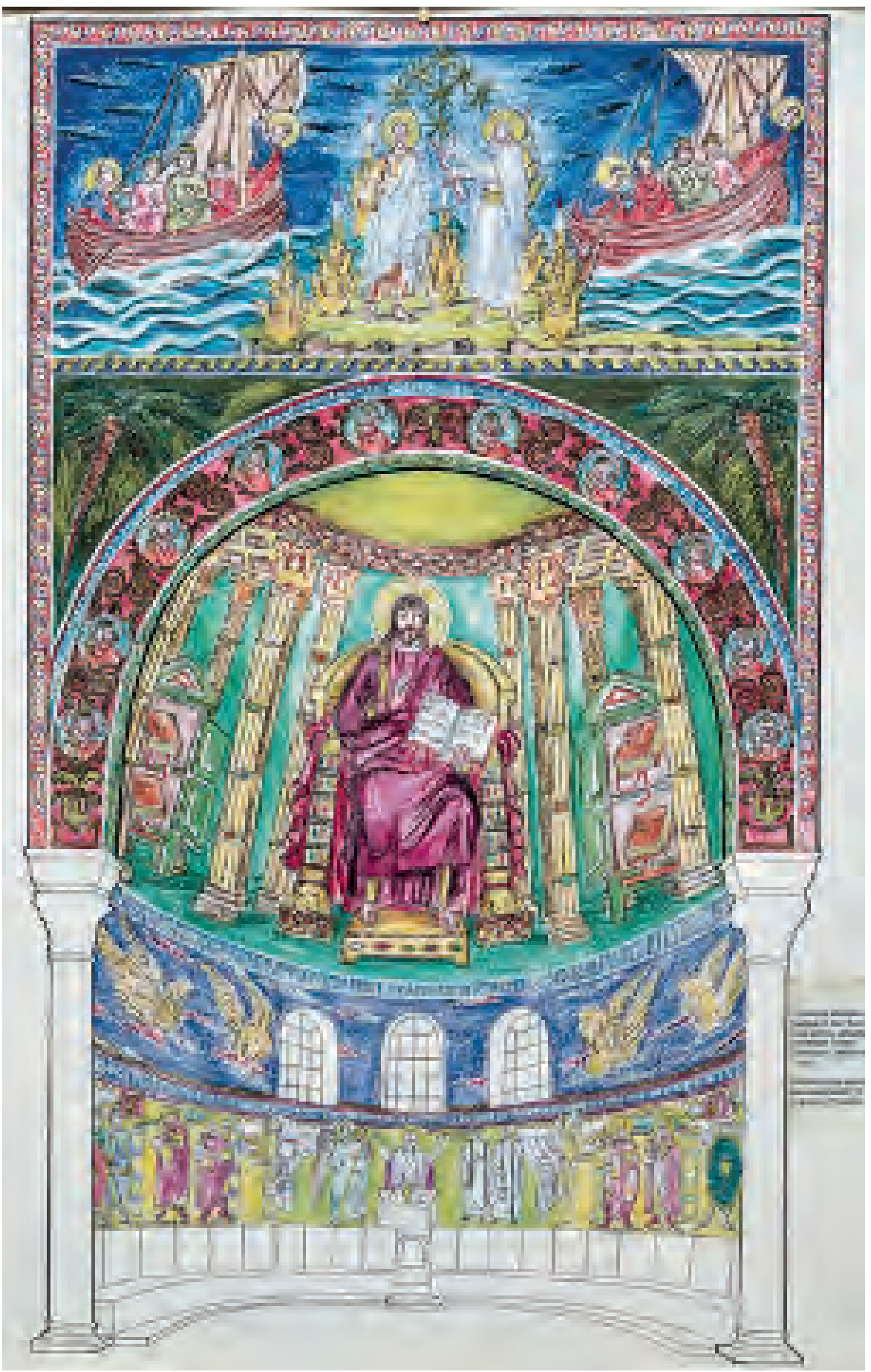

Figura 7. Plan iconográfico del ábside de San Giovanni Evangelista (Reconstrucción).

La llegada de Teodorico a Ravena, tras su victoria sobre Odoacro en el 493, reavivó la cultura musivaria ravenesa con la construcción de nuevos edificios civiles y religiosos bajo el culto arriano. La Capilla Palatina o Basílica del Redentor (futura San Apolinar Nuevo) fue uno de los principales encargos realizados por Teodorico para el culto arriano. Cuando el obispo Agnello en el 561 la transforme en iglesia católica, parte de su decoración ha de ser removida y raspada, implantando nuevas escenas en sendos paños murarios sobre las columnas de la nave, y borrando las procesiones de Teodorico 
y su esposa, junto a miembros de la Corte hacia Cristo y María (cfr. Figura 8). De esta manera, el interior del templo quedará decorado en tres bandas o registros horizontales; los mosaicos más antiguos datan de los años 520 al 526, mientras que los de la parte inferior se realizan aproximadamente en el 540 sustituyendo los de la época de Teodorico. En la parte superior, sobre las ventanas, aparecen 26 paneles que ilustran la vida de Cristo, sus milagros y el ciclo de la Pasión, donde se encuentran escenas de activa participación femenina: la curación de la hemorroísa (Mt.9:18-26), la buena Samaritana (Jn.4:5-24), el óbolo de la viuda (Lc. 21:1-4) o las Marías ante el sepulcro (Mt. 28:1-7) (Figuras 9 a 12). En todas estas escenas, los milagros de Cristo y la fe de las mujeres brindan un poderoso mensaje salvífico, conjuntamente con la muestra de abnegación y la capacidad de comunicación con el ángel, tras la resurrección y la misión que éste le encomienda a las Marías frente a los Apóstoles. Por debajo y ocupando el lugar entre las ventanas del claristorio, el espacio se ocupa con figuras de profetas y patriarcas y en la zona inferior, del lado del Evangelio se desarrolla una procesión de vírgenes que se traslada desde el puerto de Rávena hasta el otro extremo de la nave, donde aparecen representados la Virgen y el Niño. Está flanqueada por cuatro ángeles y, ante ella, los tres Magos se acercan en actitud de reverencia, portando regalos y bajo la estrella que los ha guiado (están fuertemente intervenidos y durante el s. XIX se cambiaron las coronas que tenían sobre la cabeza por unos gorros frigios, como se ve en la actualidad, siguiendo el modelo de los que adornan la túnica de Teodora en su mosaico en San Vital o en varios sarcófagos raveneses) (cfr. Figura 13). Enfrente, del lado de la Epístola, hay otro cortejo de mártires varones que sale del Palatium (presumiblemente de Teodorico), encabezado por San Martín de Tours (gran luchador contra el arrianismo) hasta el trono de Cristo, flanqueado por cuatro arcángeles.

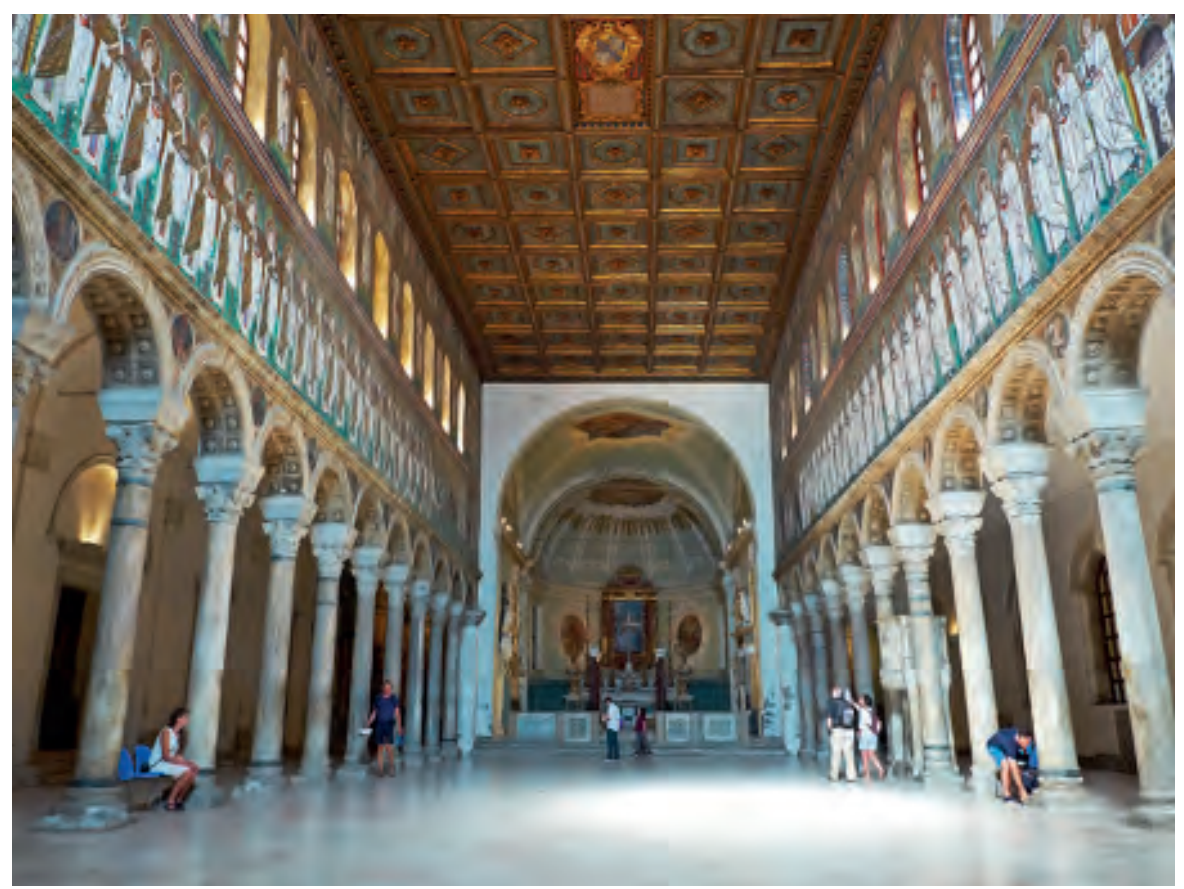

Figura 8. Interior de Sant Apollinare Nuovo en la actualidad. 

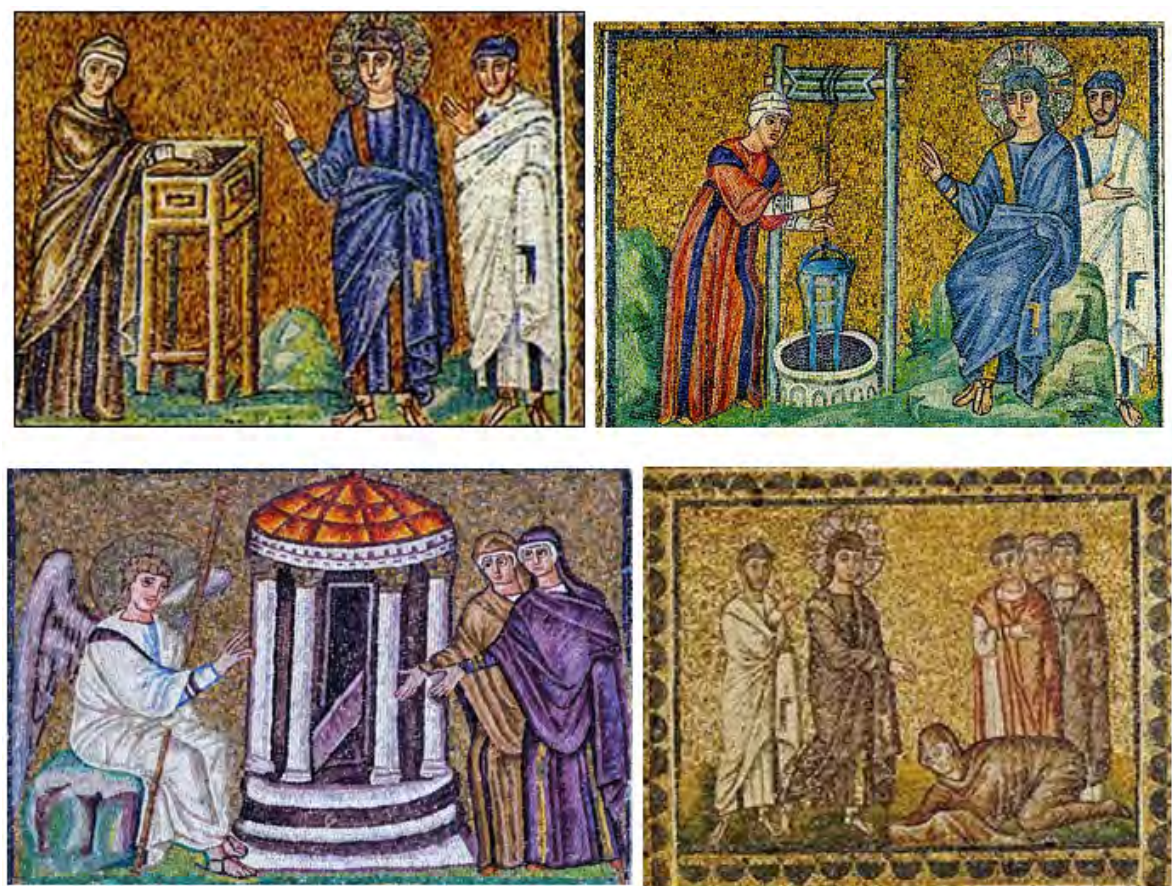

Figuras 9 a 12. el tributo de la viuda, Jesús y la buena Samaritana, Las Marías y el Ángel y la curación dela hemorroísa. Todos, mosaicos de Sant Apollinare Nuovo.

Sobre un fondo dorado y con ricas túnicas y adornos, estas procesiones son el reflejo del suntuoso protocolo y ceremonial que se estilaba en la civilización bizantina y su cesaropapismo; aunque se trata de una imagen llena de los convencionalismos plásticos propios de la estética bizantina, como la ausencia de perspectiva, la rigidez de las figuras o la frontalidad de cuerpos y rostros, esto no resta majestuosidad y colorido a las escenas ni impide calificar el conjunto como uno de los más logrados y representativos de la musivaria bizantina (Beckwith, 1997). Pese a la reiteración de tipos y posturas ajenas a la naturalidad o la falta de realismo, encontramos un intento de individualizar los personajes, al identificarlos a través de tituli con sus nombres e incorporar los atributos martiriales, y por portar todos sus respectivas coronas gemadas en manos pudorosamente cubiertas con sus vestiduras. No obstante, no debe olvidarse que no es la individualización ni el realismo lo que interesa al artesano bizantino, sino la abstracción de los rasgos más significativos de los rostros y la figura humana; de ahí el carácter atemporal y la expresividad tan poco marcada, por lo que concluimos que podría tratarse de una procesión de íconos de santos hacia Cristo y María. ${ }^{16}$ Las mujeres parecen pertenecientes a la corte bizantina por la riqueza de su vestuario, los tocados y las joyas que las adornan, en tanto los hombres parecen miembros santificados de algún colegio senatorial, todo muy en consonancia con la etiqueta palaciega de Constantinopla (cfr. Figura 14). 


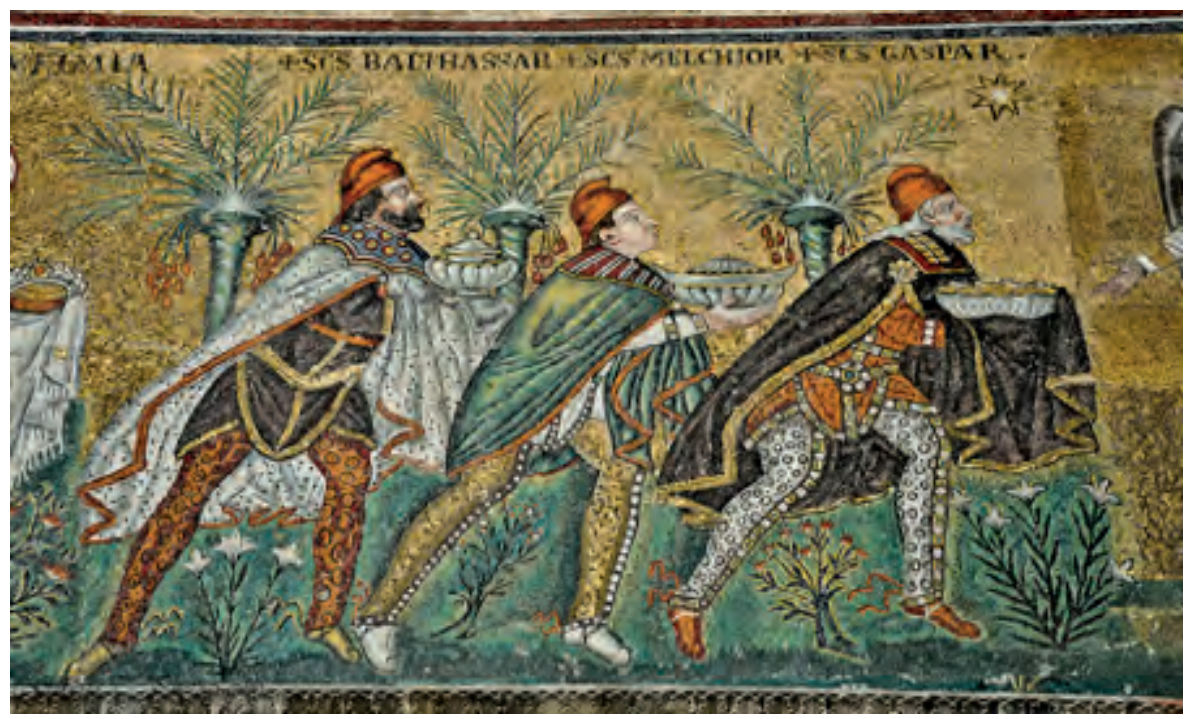

Figura 13. Los Magos hacen su ofrenda a la Virgen. Sant Apllinare Nuovo.

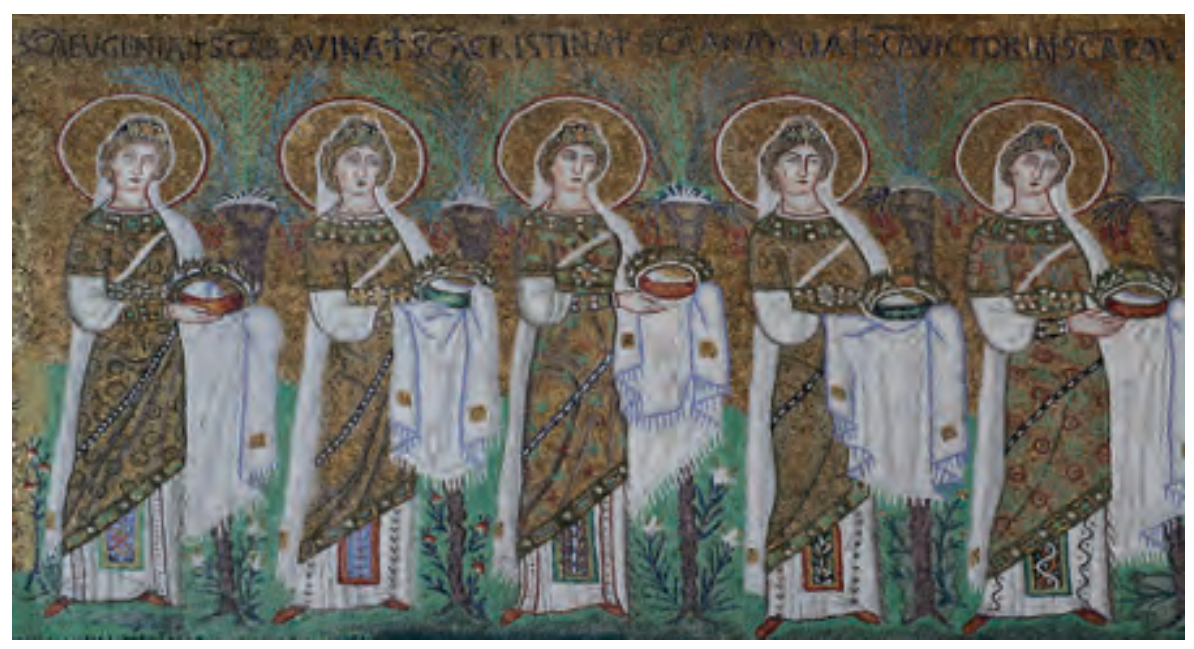

Figura 14. Procesión de santas y vírgenes. Sant Apollinare Nuovo.

La constitución de esta Capilla Palatina en templo católico eliminó de sus mosaicos muchos elementos que los relacionaban con el arrianismo y Teodorico, pero el resultado final observable a la fecha implica un grandilocuente ejemplo de maestría artística donde hombres y mujeres comparten igualitariamente en sendas procesiones un camino de santidad que arriba tanto a Cristo como a la Teotokos, la que aparece con el Niño en su regazo y ataviada como era la usanza bizantina, con su maphorion sobre los hombros y cabeza y con una estrella sobre la frente ${ }^{17}$ (cfr. Figura 15).

17 Habitualmente, en los íconos la figura de María aparece con tres estrellas, dos sobre sus hombros y una en la cabeza, emblema de su virginidad antes, durante y después del embarazo. Hans Belting (2009:cap.III) dedica un interesante análisis sobre la importancia de la imagen mariana en el arte bizantino. Cfr. Morelli (2000), Sotira (2015). 


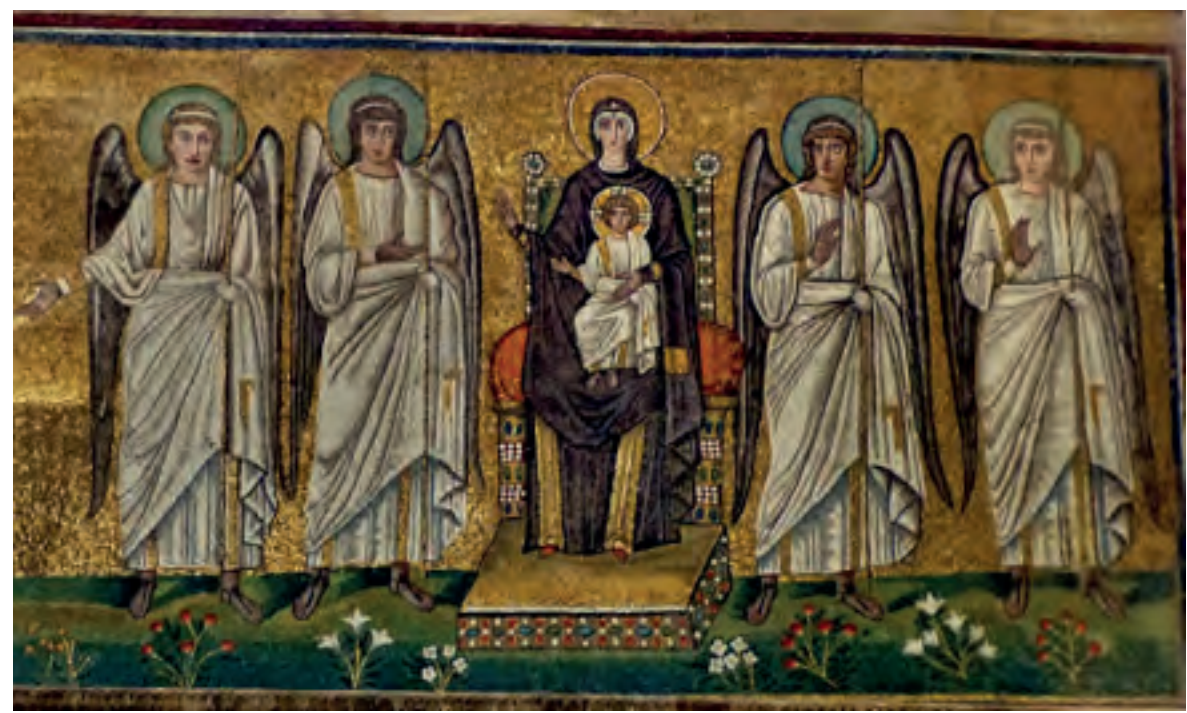

Figura 15. María Teótokos entronizada con el Niño y 4 ángeles. Sant Apollinare Nuovo.

Indudablemente, el ejemplo más acabado de arte del mosaico ravenés y sus formas retóricas o de relato religioso, político y de propaganda y a la vez uno en el que podremos encontrar otras de las mujeres que nos interesa evocar en este artículo, es la Basilica de San Vital, ${ }^{18}$ donde una serie de mosaicos exaltan un programa salvífico en los muros del Presbiterio, además de dos reconocidas procesiones que iconográficamente, parecen confluir en el ábside: la de Justiniano y la de la emperatriz Teodora. ${ }^{19}$ (cfr. Figura 16). Fue comenzada hacia el 525 por el obispo Eclesio (521-532) tras una embajada en Constantinopla, y financiada por el banquero local Juliano Argentario. Continuada por el obispo Víctor (538-545), fue consagrada hacia el 547 bajo el obispado de Maximiano (546-556), del cual el Museo Arzobispal guarda una preciosa Cátedra Ebúrnea ${ }^{20}$ (cfr. Figuras 17 a 19).

18 Inmaculada Rodríguez Moya (2004) nos habla del ceremonial bizantino de coronación y de la solemnidad
con la que las procesiones se desarrollaban ya habían sido impuestas por Constantino, siendo Justiniano en este mosaico la imagen viva de aquel emperador.

19 Según el funcionario Juan Lydus, la juzgaba "superior en inteligencia a todos los hombres que habían existido hasta entonces", además de que Procopio reproduce las palabras que sellaron el fututo de la pareja frente a la revuelta Niké: "en cuanto a si está bien que una mujer destaque entre los hombres o muestre atrevimiento donde otros vacilan, no creo que la crisis actual nos permita una u otra opinión. [...] Mantengo que la huida es ahora más que nunca inoportuna [...] Ningún hombre nacido puede encontrarse con la muerte. Pero convertirse en un fugitivo es algo intolerable para un emperador. [...] Sin embargo [...] por lo que a mí se refiere, me atengo al viejo dicho de que la púrpura es una hermosa mortaja". (Beckwith, 1997:113). Este extracto de parlamento, la pinta de cuerpo entero en su integridad, decisión y poder en la Corte justinianea.

20 Esta magnífica pieza se considera un regalo del propio Justiniano para la consagración de San Vital en la cual trabajaron, probablemente, cuatro artesanos con un rico programa iconográfico descripto así: el frontal de la cátedra, debajo del cojín, presenta cinco paneles con el Bautista y los cuatro Evangelistas, con listones decorados con pámpanos y un delicado bestiario, que podrá ser visto a lo largo de otras bandas de separación entre placas y para completar a modo de marco cada una de ellas. El interior del respaldo y directamente a la vista, presenta escenas de la vida de Cristo, especialmente sacadas de los Evangelios Apócrifos, donde María es protagonista: La Anunciación, la demostración de la virginidad de María a través de la prueba del agua, el sueño de José y el viaje a Belén, la Natividad, el milagro de la partera incrédula y la Virgen con el Niño. Parte externa del respaldo: es donde faltan más placas, quedando apenas siete de las catorce y contienen escenas de la vida de Cristo: bautismo, el ingreso a Jerusalén, la multiplicación de panes y peces, las bodas de Canaá, la curación del ciego, el encuentro con la samaritana y la comida de la multitud tras el milagro de la multiplicación de panes y peces. Los costados, donde se relatan episodios de la vida de José, el hebreo. En todos los casos, la presencia femenina es de suma importancia, además de la de María, aparecen otras mujeres como la esposa de Putifar; Bala, la madrastra de José, mujeres asistentes/ comensales al milagro de los peces y panes o una mujer que ve por la ventana el prendimiento de José tras ser acusado por la esposa de Putifar. Ha sido expoliada y reconstruida a lo largo del tiempo, pero, tras largos 


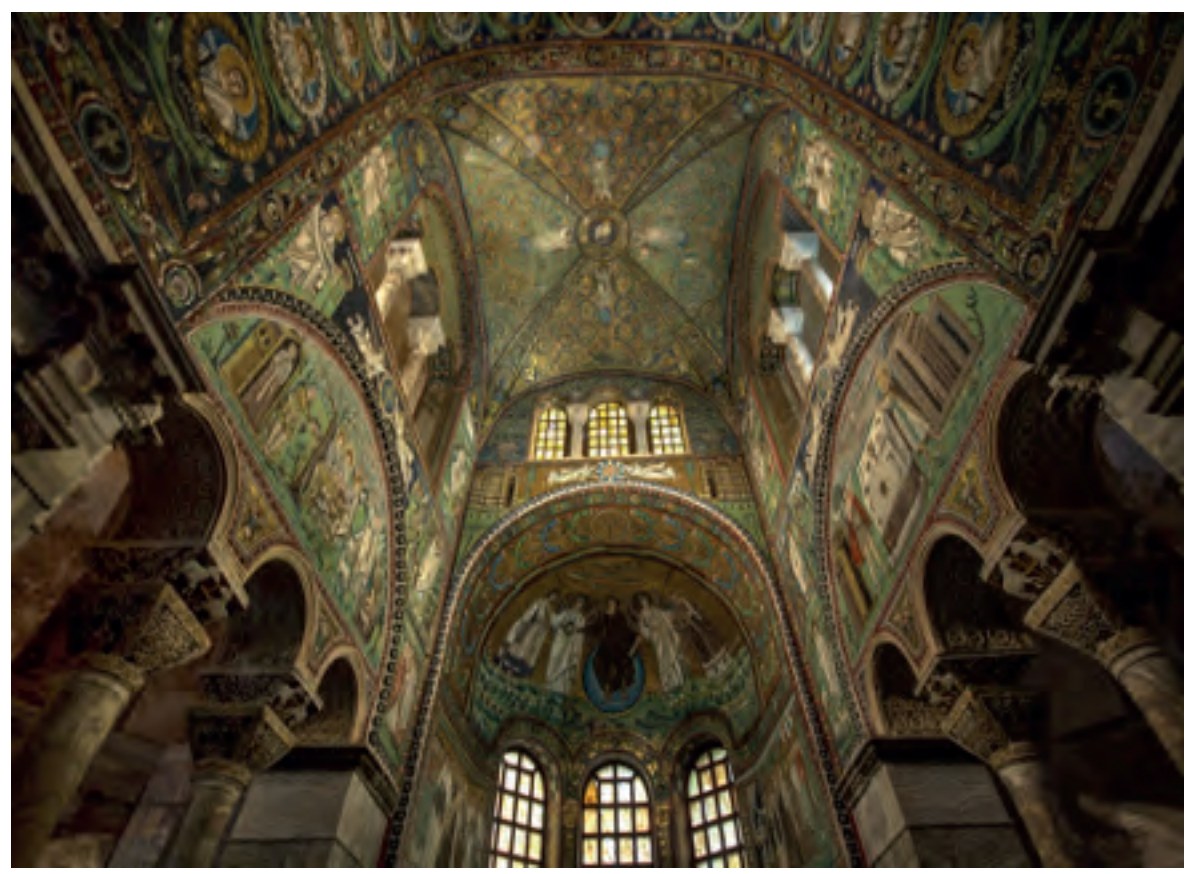

Figura 16. Vista del interior del Presbiterio de San Vitale.

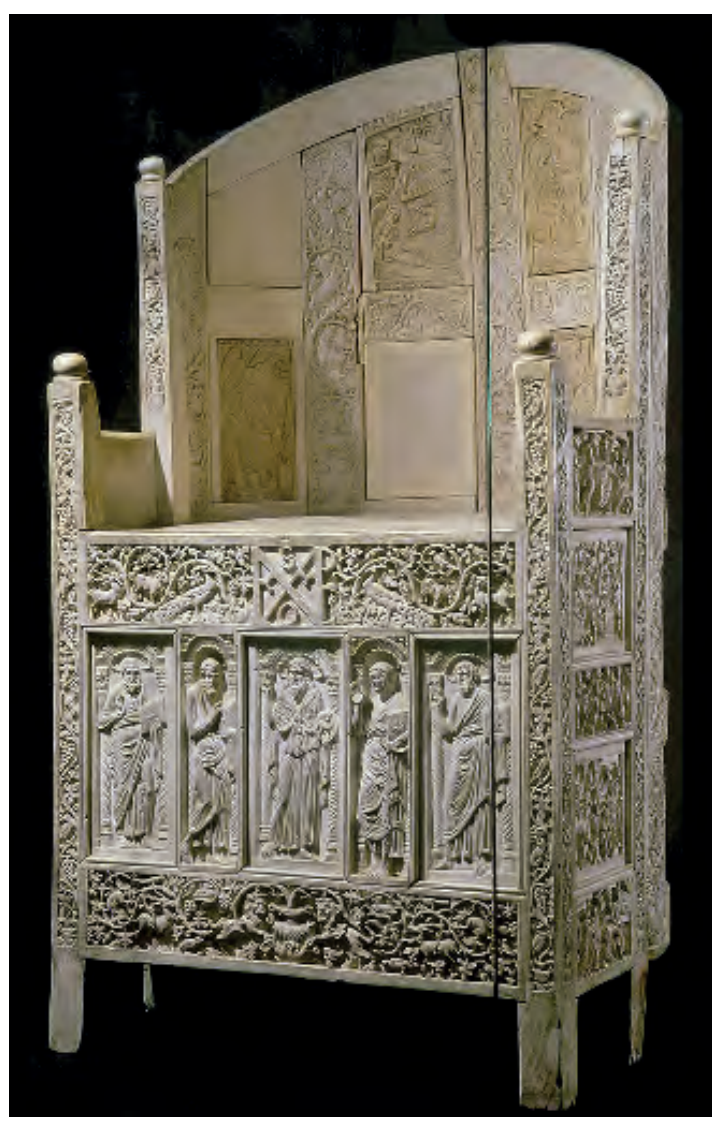

Figura 17. Cátedra Ebúrnea del Obispo Maximiano - Museo Archiepiscopal de Ravena.

estudios, las placas de marfil que la cubren fueron reubicadas en el lugar original en 1956, pese la desaparición o deterioro de algunas de sus piezas y habiéndose recuperado algunas que estaban en colecciones privadas o museos de Europa. 


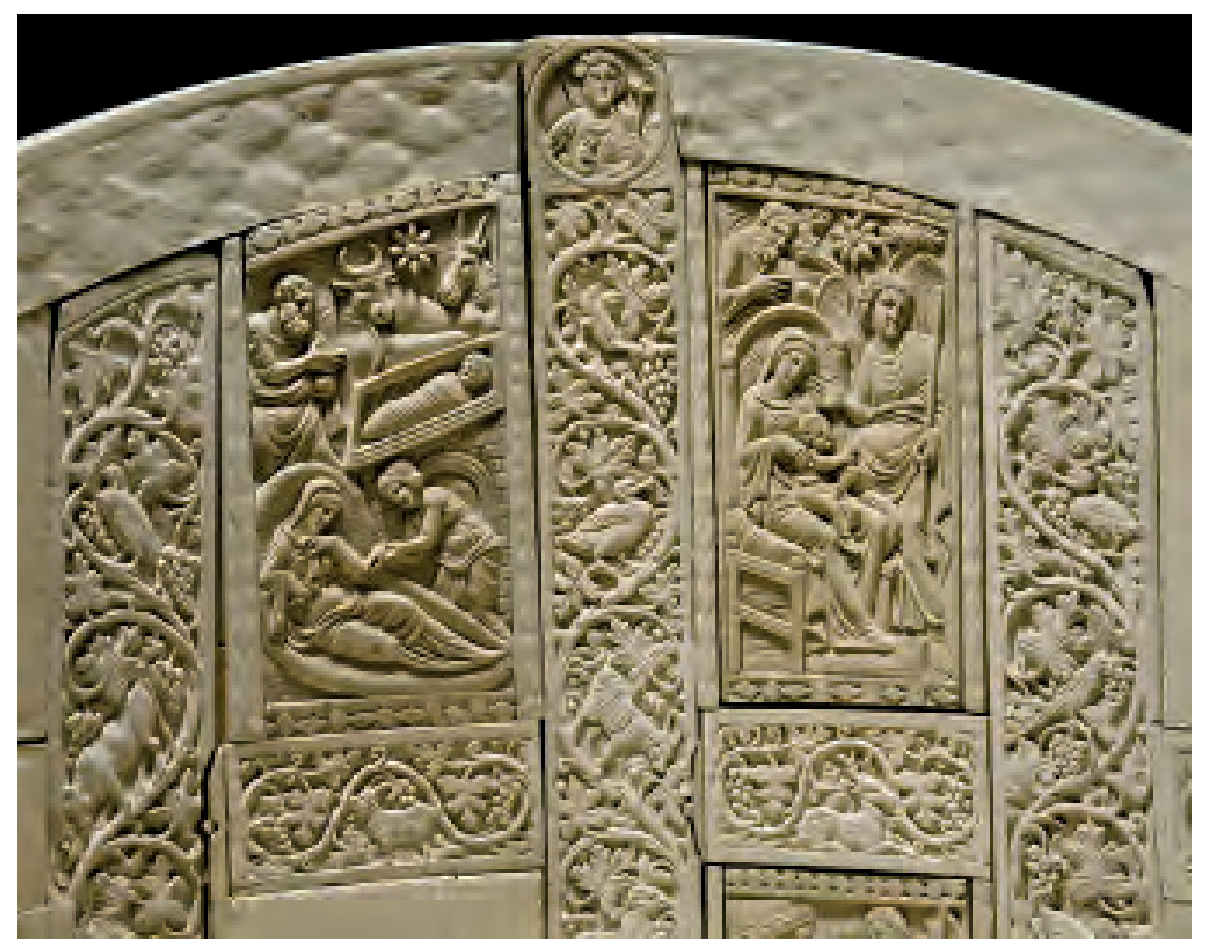

Figura 18. Cátedra Ebúrnea del Obispo Maximiano. Detalle del respaldo - Museo Archiepiscopal de Ravena.

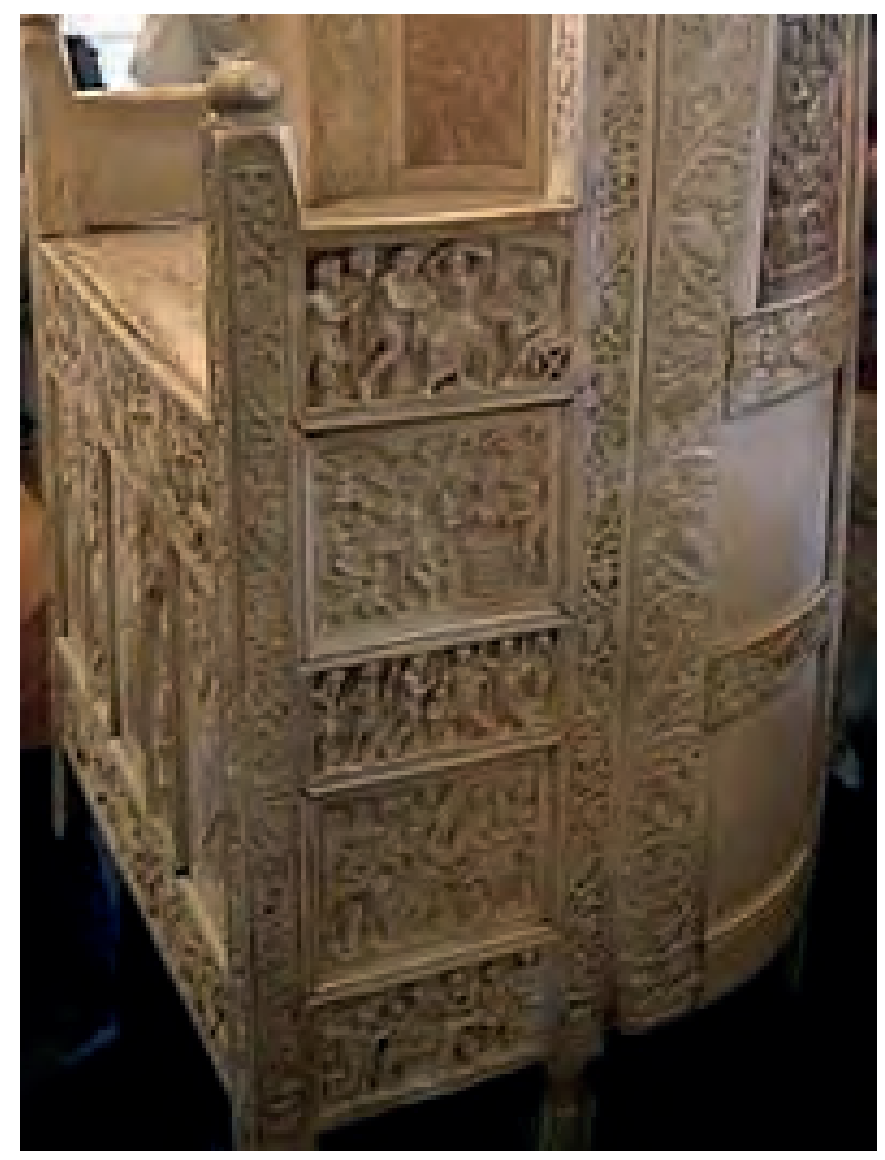

Figura 19. Cátedra Ebúrnea del Obispo Maximiano. Detalle del costado izquierdoMuseo Archiepiscopal de Ravena. 
Nos detendremos sólo en dos mosaicos de este vasto programa iconográfico, por una cuestión de espacio y por ser el objetivo de nuestro estudio: del lado del Evangelio, al lado de la procesión de Justiniano se encuentra una doble escena de la vida de Abraham. Se trata de dos momentos decisivos en su vida: de un lado del luneto, el encuentro con los tres desconocidos en el encinar de Mamrée ${ }^{21} \mathrm{y}$, del otro, el sacrificio de Isaac. En ambos casos, la voluntad divina triunfa mostrando que nada le es imposible y la obediencia salva, aún a costa del sacrificio del primogénito y unigénito. Este paralelismo con la figura de Cristo no es casual, en tanto la actitud de Sara es lo que resalta la fuente: el temor de lo humano frente a las limitaciones de la finitud. Sabía que ambos eran muy mayores y no podrían tener un hijo de no mediar causas sobrenaturales. Esta correspondencia bíblica se hace paralela al caso de María, que si bien no era anciana y ya estéril, era virgen y su primogénito sería sacrificado, como el cordero de Isaac (cfr. Figura 20).

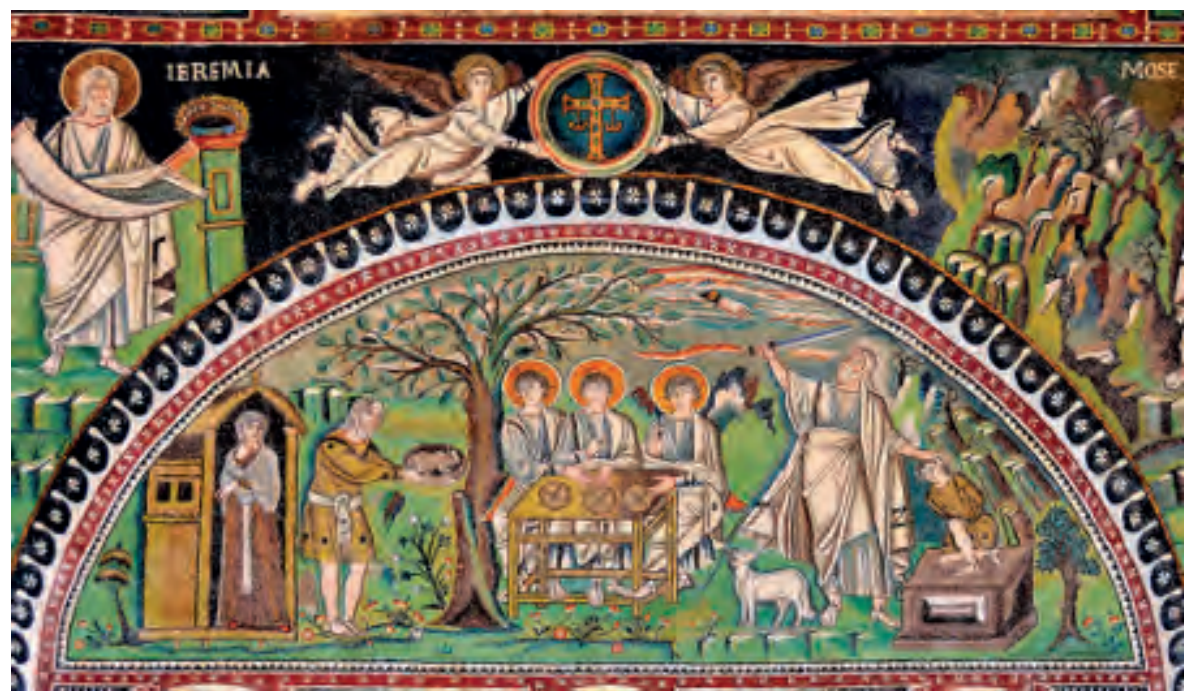

Figura 20. Luneto del lado del Evangelio: Episodios en la vida de Abraham. San Vitale.

En el lado de la Epístola, en el Presbiterio, podemos admirar la procesión de Teodora, la que se nos muestra engalanada con joyas, diadema y collar, vestida con una túnica púrpura, bordada en su parte inferior con las figuras de los Magos. De mirada orgullosa e impasible, al decir de Beckwith (1997), lleva

21 Dice Génesis 18:1-15: “1Después le apareció Jehová en el encinar de Mamré, estando él sentado a la puerta de su tienda en el calor del día. 2 Y alzó sus ojos y miró, y he aquí tres varones que estaban junto a él; y cuando los vio, salió corriendo de la puerta de su tienda a recibirlos, y se postró en tierra, 3y dijo: Señor, si ahora he hallado gracia en tus ojos, te ruego que no pases de tu siervo. 4Que se traiga ahora un poco de agua, y lavad vuestros pies; y recostaos debajo de un árbol, 5 y traeré un bocado de pan, y sustentad vuestro corazón, y después pasaréis; pues por eso habéis pasado cerca de vuestro siervo. Y ellos dijeron: Haz así como has dicho. 6Entonces Abraham fue de prisa a la tienda a Sara, y le dijo: Toma pronto tres medidas de flor de harina, y amasa y haz panes cocidos debajo del rescoldo. 7 Y corrió Abraham a las vacas, y tomó un becerro tierno y bueno, y lo dio al criado, y éste se dio prisa a prepararlo. 8Tomó también mantequilla y leche, y el becerro que había preparado, y lo puso delante de ellos; y él se estuvo con ellos debajo del árbol, y comieron. 9Y le dijeron: ¿Dónde está Sara tu mujer? Y él respondió: Aquí en la tienda. 10Entonces dijo: De cierto volveré a ti; y según el tiempo de la vida, he aquí que Sara tu mujer tendrá un hijo. Y Sara escuchaba a la puerta de la tienda, que estaba detrás de él. 11Y Abraham y Sara eran viejos, de edad avanzada; y a Sara le había cesado ya la costumbre de las mujeres. 12Se rió, pues, Sara entre sí, diciendo: ¿Después que he envejecido tendré deleite, siendo también mi señor ya viejo? 13Entonces Jehová dijo a Abraham: ¿Por qué se ha reído Sara diciendo: ¿Será cierto que he de dar a luz siendo ya vieja? 14¿Hay para Dios alguna cosa difícil? Al tiempo señalado volveré a ti, y según el tiempo de la vida, Sara tendrá un hijo. 15Entonces Sara negó, diciendo: No me reí; porque tuvo miedo. Y él dijo: No es así, sino que te has reído." Más adelante, Sara es reconocida a pesar de su lógica reacción humana anterior, en Hebreos 11:11-12: "También por la fe Sara misma recibió fuerza para concebir, aun pasada ya la edad propicia, pues consideró fiel al que lo había prometido. 12Por lo cual también nació de uno (y éste casi muerto con respecto a esto) una descendencia como las estrellas del cielo en número, e innumerable como la arena que está a la orilla del mar." 
en sus manos un cáliz de oro y pareciera detenerse un instante para cruzar la mirada con el observador, para continuar con su marcha ceremonial. Está acompañada de dos cortesanos y un cortejo de damas ricamente ataviadas. Inmediatamente detrás de la emperatriz está Antonia (que podría haber sido su consuegra), la hija imperial, Juana y detrás un grupo de damas de la Corte. Todas vestidas elegantemente con vistosas sedas multicolores con bordados y aplicaciones de materiales semipreciosos en el mosaico. Por delante, un cortesano entreabre un cortinaje frente al cual aparece una pequeña fuente de la que mana agua. Podría tratarse o bien del momento en que la emperatriz sale del palacio, o bien de un interior eclesiástico, ${ }^{22}$ en tanto Teodora se encuentra frente a un nicho coronado por una venera, resaltando al personaje retratado. A su lado, pende un dosel que cobija a las damas (cfr. Figuras 21 y 22).

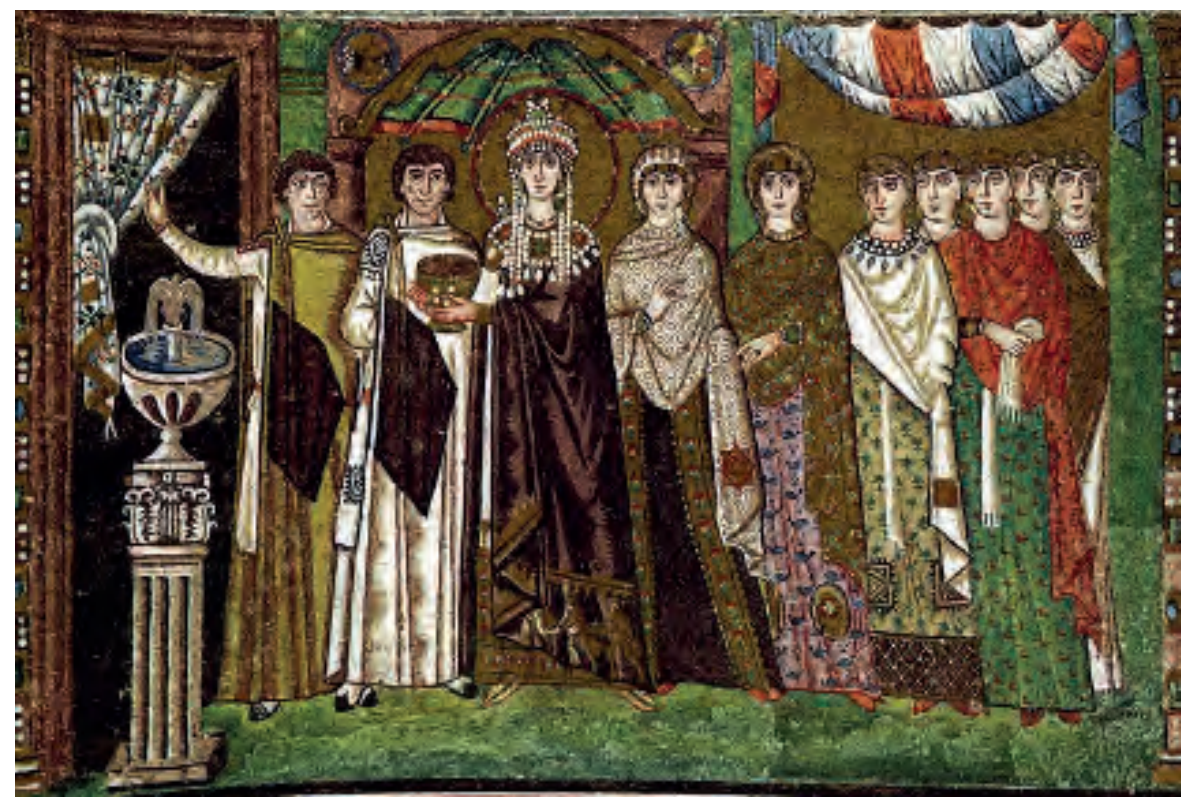

Figura 21. Lado de la Epístola: Procesión de la Emperatriz Teodora. San Vitale.

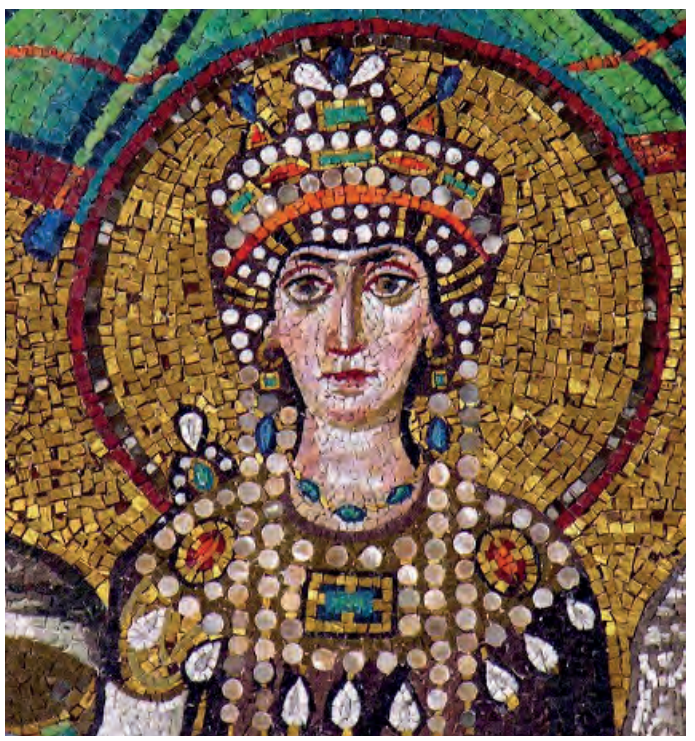

Figura 22. Lado de la Epístola: Detalle del retrato de la Emperatriz Teodora. San Vitale.

22 Beckwith (1997:127-128) desarrolla la idea sobre el debate que se ha dado respecto de si esta escena era verosímil o una construcción del artesano para colocar a la emperatriz en situación de procesión. 
Dentro del mismo complejo edilicio (hoy Museo Arzobispal de Ravena), se encuentra la Capilla de San Andrés, pequeño oratorio para los arzobispos de la sede edificado hacia el 495, bajo el reinado de Teodorico. Arriana en su origen y dedicada al Salvador, fue finalizada en 520. A pesar del expolio y las intervenciones del Barroco, aún conserva bellísimos mosaicos en los muros y en la bóveda sobre la planta de cruz griega. Es interesante esta capilla pues conserva una importante cantidad de clipea con retratos de apóstoles, santos y santas, como Felicitas, Eufimia, Daría, Cecilia, Eugenia y Perpetua (Deliyannis, 2010:194ss.), todas mártires de los tres primeros siglos del cristianismo occidental y oriental, que a través de su fortaleza y entrega, alcanzaron la palma pero también sirvieron de ejemplo a numerosos fieles, aunque, curiosamente, no están retratadas con halo, como ninguno de los santos o Apóstoles ${ }^{23}$ (cfr. Figuras 23 a 26).

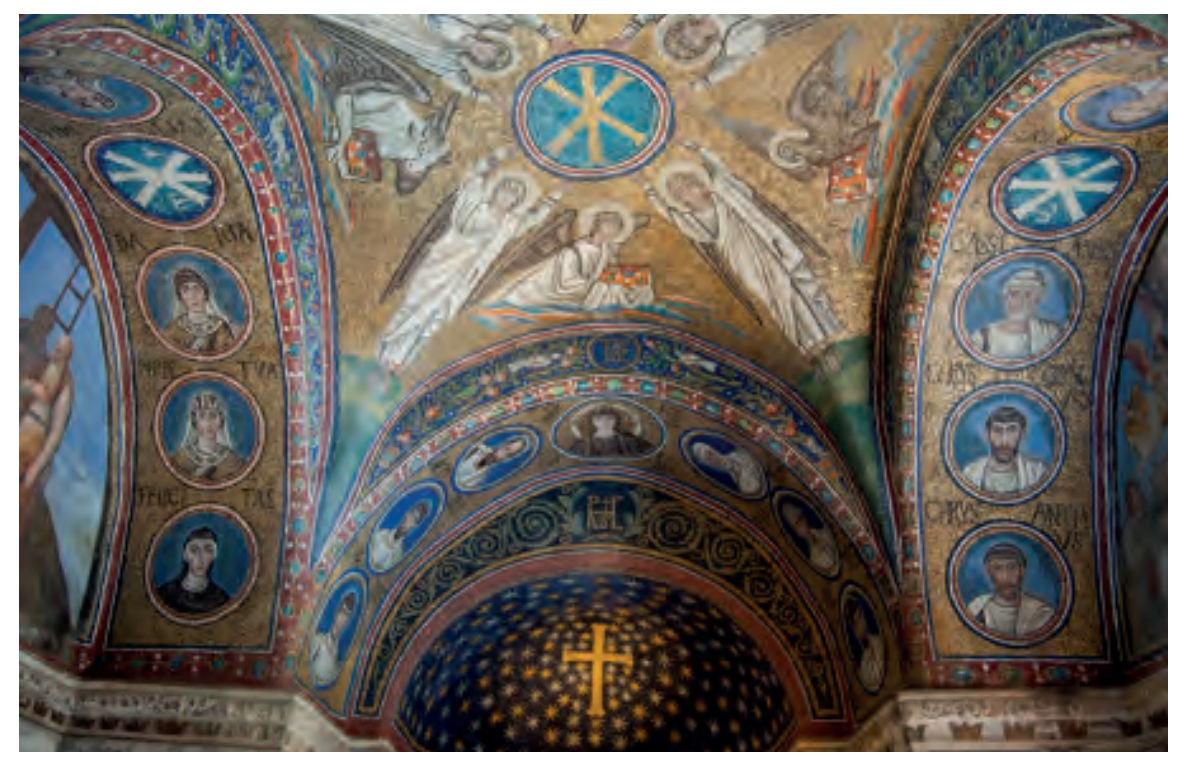

Figura 23. Capella di Sant’Andrea - Vista parcial de la bóveda.

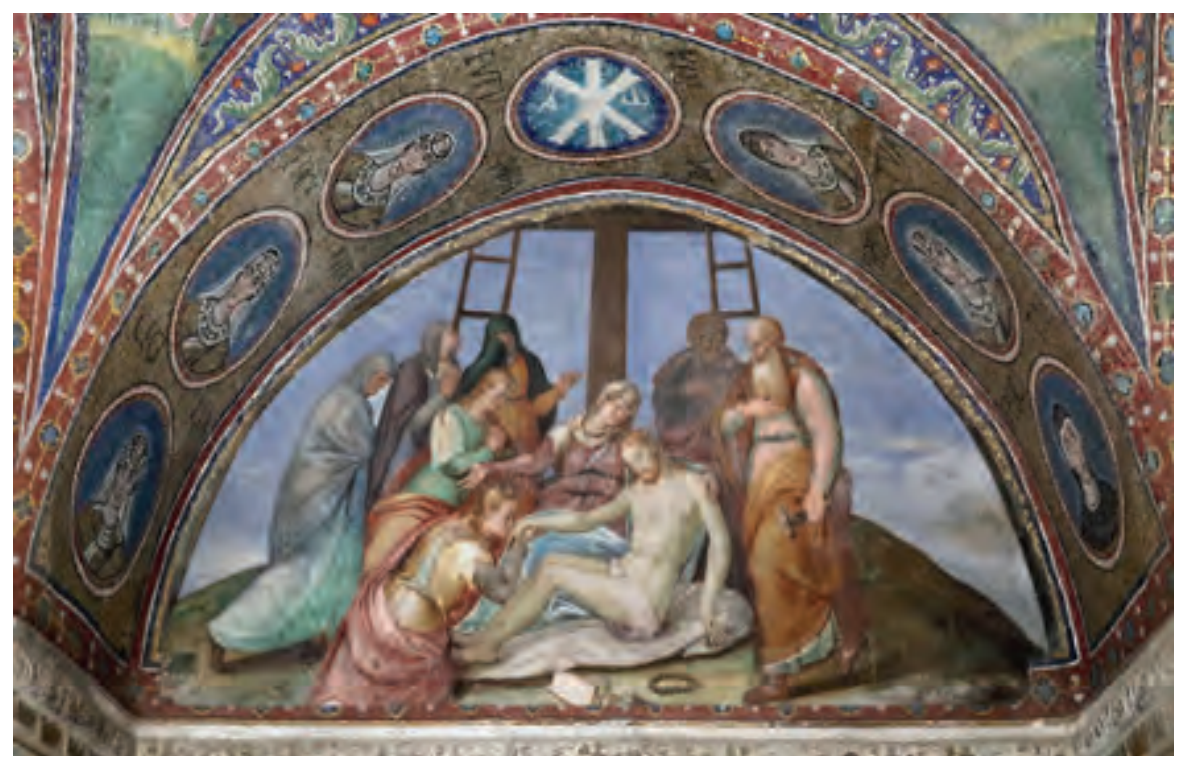

Figura 24. Capella di Sant'Andrea - Vista parcial de la bóveda - Luneto manierista con una escena del Descendimiento de la Cruz.

23 Un reciente texto que exalta a las mujeres que aparecen en los mosaicos raveneses es el de Marchetti (2017). 


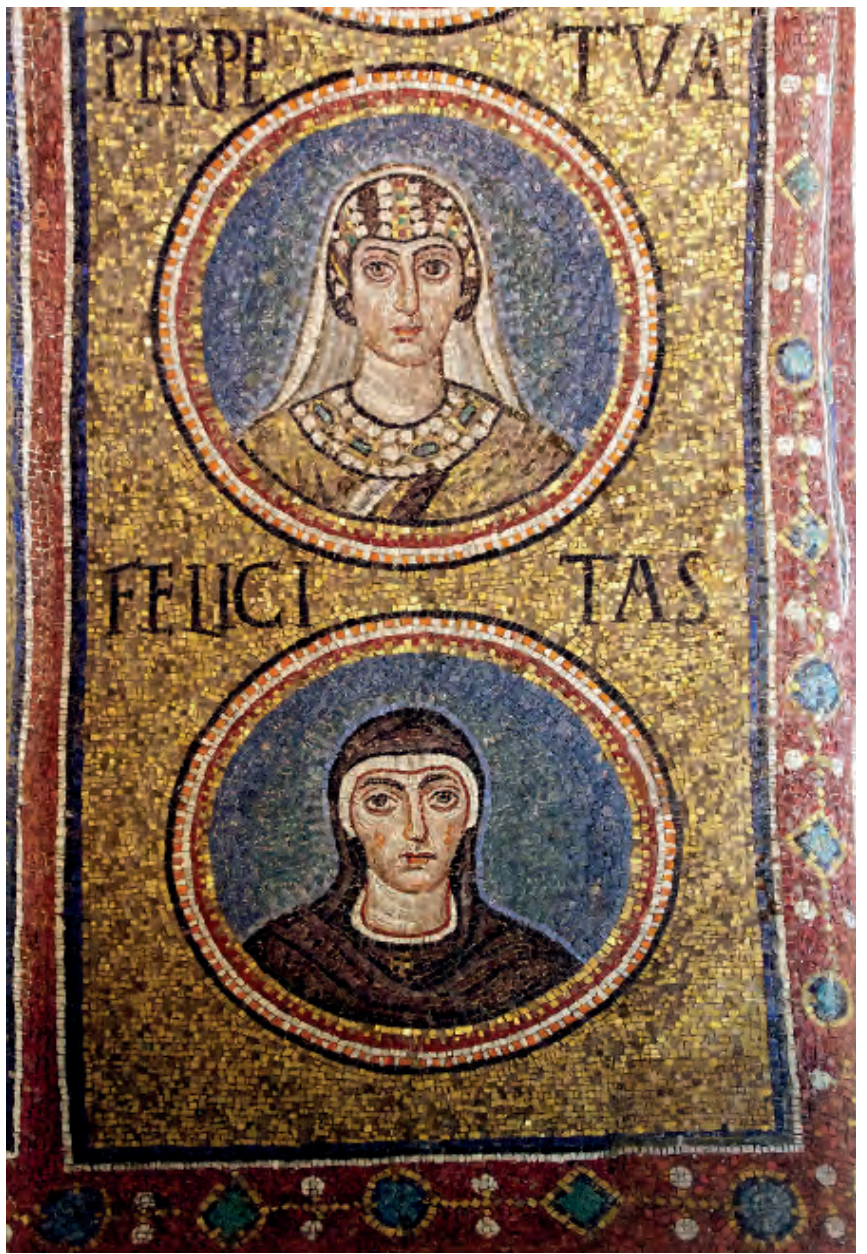

Figura 25. Capella di Sant'Andrea - Santas Perpetua y Felicitas.

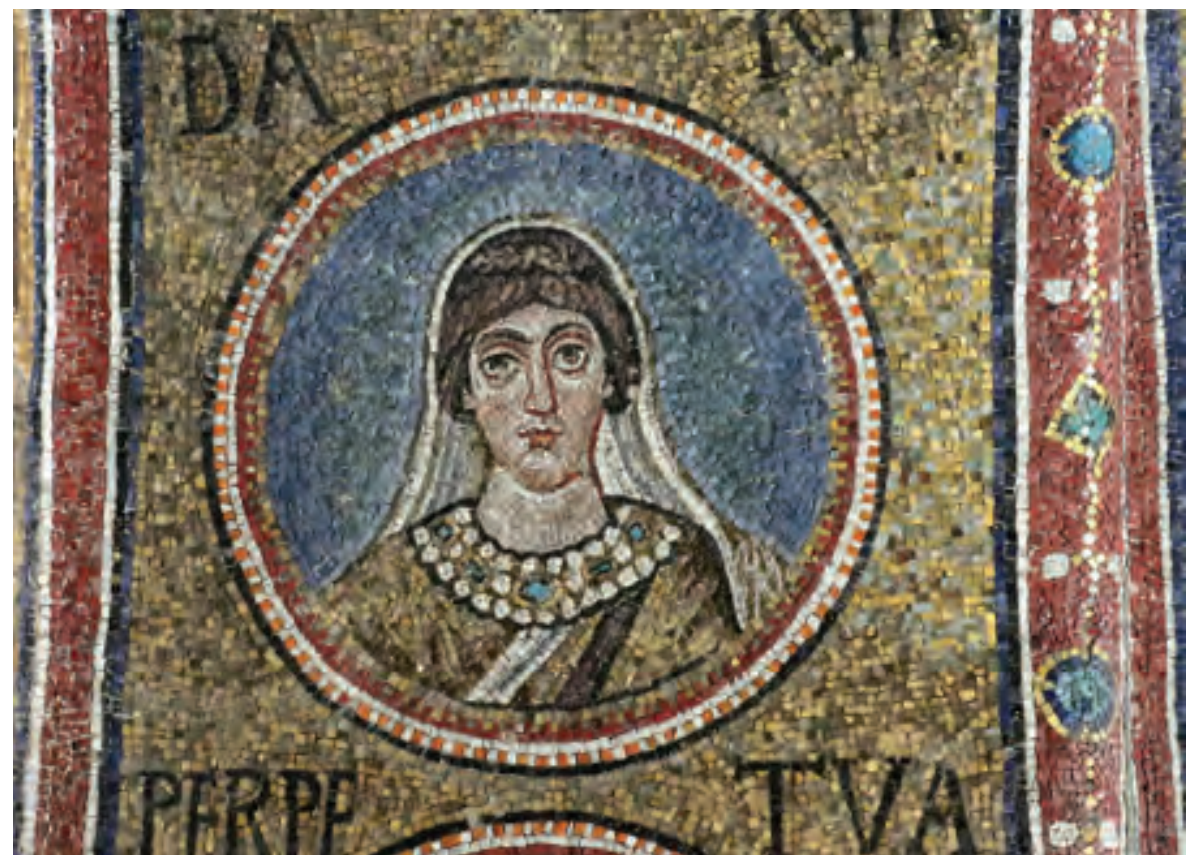

Figura 26. Capella di Sant'Andrea - Santa Daria. 
En conclusión, Ravena nos ha dejado una importante cantidad de preciosos mosaicos que relatan diversos episodios, imágenes o aspectos políticos y religiosos, de los cuales muchos de ellos, dedicados a mujeres que por su actividad política e histórica, condición o por ser catalizadoras de acciones en el marco de la Salvación, ocuparon lugares destacados en estos ciclos iconográficos. Mujeres en el mundo o mujeres de las Escrituras. Todas imprescindibles a la hora de relatar o completar un discurso político, religioso o también, como informativo de hábitos sociales o de vestimenta, más allá de las influencias culturales que supieron ejercer en su momento sobre artistas, comitentes, fieles y hoy, sobre nosotros. Esas mujeres nos contemplan espléndidas desde los mosaicos raveneses. Merecen su lugar y su eternidad petrificada en miles de teselas. 


\section{Q Bibliografía}

\section{Fuentes}

»Agnellus of Ravenna, Liber Pontificalis Ecclesiae Ravennatis. (1878). En: HolderEgger, O. (ed.). Monumenta Germaniae Historica, Scriptores rerum Langobardicarum et Italicarum saec. VI-IX. Hannover, 265-391.

»Deliyannis, D.M. (ed.) (2004). The Book of Pontiffs of the Church of Ravenna. Washington: The Catholic University of America Press.

\section{Bibliografía crítica}

" AA. VV. (2010). Un año de mujeres. Oviedo: Instituto Asturiano de la Mujer.

» Beckwith, J. (1997). Arte paleocristiano y bizantino. Madrid: Cátedra.

» Bayet, C. (2015). L'art byzantin. New York: Parkstone.

»Belting, H. (2009). Imagen y culto. Una historia de la imagen anterior a la era del arte, Madrid: Akal.

»Bertelli, C. (2012). La storia dell'arte. Milano: Pearson.

» Bovini,G. (2006). Ravenna arte e storia. Ravenna: Longo editore.

» Castelnuovo, E.; Sergi, G. (dirs.) (2013). Arte e historia en la Edad Media. Volumen II. Madrid: Akal.

" Cereda E.; Dall'Ara V. (2014). Il Museo Nazionale di Ravenna: una nuova narrazione museográfica, Universita' di Bologna, tesis de Laurea Archeologia eprogetto di Architettura.

» Cirelli, I. E. (2008). Ravenna, archeologia di una città. Firenze: All'Insegna del Giglio.

»Concina E.; Flores David, A.; Guidetti, M. (2011). Luce dell'invisibile. Itinerari del mosaico intorno al Mediterraneo orientale. Venezia: Marcanum Press.

"Connor, C. (2016). Saints and Spectacle. Byzantine mosaics in their cultural setting. New York: Oxford University Press.

»Cortesi, G. (1978). La Chiesa di Santa Croce di Ravenna alla luce degli ultimi scavi e ricerche. Ravenna: Edizione del Girasole.

" Coscarella A.; De Santis P. (2012). Martiri, santi, patroni: per una archeologia della devozione. Atti X Congresso Nazionale di Archeologia Cristiana. Cosenza: Università della Calabria.

»David, M. (ed.). La Basilica di Santa Croce. Nuovi contributi per Ravenna tardoantica. Ravenna: Edizione del girasole.

»Deliyannys, D. M. (2010). Ravenna in Late Antiquity. New York: Cambridge University Press.

" Farioli Campanati, R. (1991). Ravenna, Chiesa di San Giovanni Evangelista: frammenti musivi del pavimento del 1213, in Catalogo mostra "Ravenna Capitale", a cura di 
Franco Faranda. Milano: Fabbri Editore,

» Ferraiuolo, A. (2018). L'Impero bizantino. Roma: Passerino.

" Gearhart, H. C. (2010). Theophilus' On Diverse Arts: The Persona of the Artist and the Production of Art in the Twelfth Century (tesis de doctorado en Artes). University of Michigan

"Grabar, A. (1960). La Edad de Oro de Justiniano. Desde la muerte de Teodosio hasta el Islam. Madrid: Aguilar.

"Grabar, A. (1967) El primer arte cristiano. Madrid: Aguilar.

" Kean, R. M (2013). The complete chronicle of the emperors of Rome. Vol. 2. Shropshire: Reckless.

» Kiecol, D. (2017). Mosaics. Paris: Könemann.

» Marchetti, G. (ed.) (2017). Le donne nei mosaici di Ravenna. Ravenna: Episcopato di Ravenna.

" Morelli G. (2000). Memorie d'eterno: i mosaici teodoriciani di S. Apollinare Nuovo e il Codice Purpureo di Rossano. Ravenna: Danilo Montanari Editore.

" Novara Piolanti, P. (1996). "Lo scavo dell'abside e del presbiterio della Chiesa di S. Giovanni Evangelista in Ravenna (aa. 1919-1921): evidenze archeologiche e quesiti ancora aperti". Corsi di Cultura sull'Arte ravennate e bizantina XLII, 219-242.

» Novara Piolanti, P.; Rinaldi A. (ed.) (2013). Restauri dei Monumenti paleocristiani e Bizantini di Ravenna. Ravenna: UNESCO.

"Reginelli, A. (2017). 400. Ultimo secolo dell'impero. Roma: s/d

» Rizzardi, C. (ed.) (2005). Venezia e Bisanzio. Aspetti della cultura artistica bizantina da Ravenna a Venezia (V-XIV secolo). Venezia: Eadem.

» Rizzardi, C. (2011). Il mosaico a Ravenna. Ideologia e arte. Bologna: Ante quem.

» Roncuzzi, I. F.; Fiorentini, E. (2001). Mosaico. Materiali, tecniche e storia. Ravenna: MWeV editore.

"Rodríguez Moya, I. (2004). "A Deo coronato. La coronación imperial en el arte". En: Heinmann, H.-D.; Knippschild, S.; Mínguez, V. (eds.). Ceremoniales, ritos y representación del poder. Castelló de la Plana: Universitat Jaume I, 205-246.

》 Rossi, F. (1970). La mosaïque. Peinture de Pierre. Milano: Alfieri \& Lacroix Editore.

"Sotira, L. (2015). "Ravenna tra Oriente e Occidente: le teofanie absidali di età giustinianea". En: Trovabene, G. (ed.). Atti del XII Colloquio AlEMA Venezia, 11-15 settembre 2012. Paris: Aiema, 11-15.

"Talbot Rice, D. (2000). El arte en la época bizantina. Barcelona: Destino.

» Mitalaitè, K.; Vasiliu, A. (coord.) (2017). L'icône dans la pensé et dans l'art. Constitutions, contestations, réinventionsde la notion d'image divineen contexte chrétien. Turnhout: Brepols.

"Wickham, C. (1981). Early medieval Italy. Central power and local society. 400-1000. London: Macmillan. 
